University of Rhode Island

DigitalCommons@URI

Open Access Master's Theses

1987

\title{
Children's Conceptions of Anger
}

Anthony Scioli

University of Rhode Island

Follow this and additional works at: https://digitalcommons.uri.edu/theses

\section{Recommended Citation}

Scioli, Anthony, "Children's Conceptions of Anger" (1987). Open Access Master's Theses. Paper 1711. https://digitalcommons.uri.edu/theses/1711

This Thesis is brought to you for free and open access by DigitalCommons@URI. It has been accepted for inclusion in Open Access Master's Theses by an authorized administrator of DigitalCommons@URI. For more information, please contact digitalcommons-group@uri.edu. 
CHILDREN'S CONCEPTIONS OF ANGER

BY

ANTHONY SCIOLI

A THESIS SUBMITTED IN RARTIAL FULFILLMENT OF THE REQUIREMENTS FOR THE DEGREE OF

MASTER OF ARTS

IN

PSYCHOLOGY

UNI VERSITY OF RHODE ISLAND

APRIL 1987 


\section{ABSTRACT}

Children's conceptions of anger were examined in three groups of children ages 6-7, 8-9, and 11-12. A serles of open-ended and semistructured questions were used to investigate five parameters of anger; instigations, bodily reactions, consequences, duration, and perceptions of sexdifferences. Chlldren's conceptions were found to vary considerably depending on age and sex of the child, and the particular target of anger. older children tended to perceive a larger set of instigations which might result in anger, expected their experiences to last longer, were more likely to report feelings of stiffness or tightness as a result of anger, and to percelve sex-differences. The findings are discussed in the context of theorles of emotion development and the issue of continuity/discontinuity. 


\section{ACKNOWLEGEMENTS}

I would like to thank all the members of my thesis committee, Henry Biller, Joseph Rossi, Albert silverstein and Galen Johnson for their advice and encouragment.

special thanks are due to my major professor, Henry Biller, who provided support and assistance from the inception of this study. Joe Rossi gave generously of his time and his help with the data analysis was invaluable. I would like to thank both Al silverstein and Galen Johnson for the many helpful and stimulating discussions concerning historical and philosophical 1ssues in Psychology.

I am Indebted to Mr. Richard Hines and the rest of the staff at West Kingston Elementary school for all their help in coordinating the interviews.

Finally, I would like to thank my entire family for all their support and encouragement during my years as a graduate student. 
Page

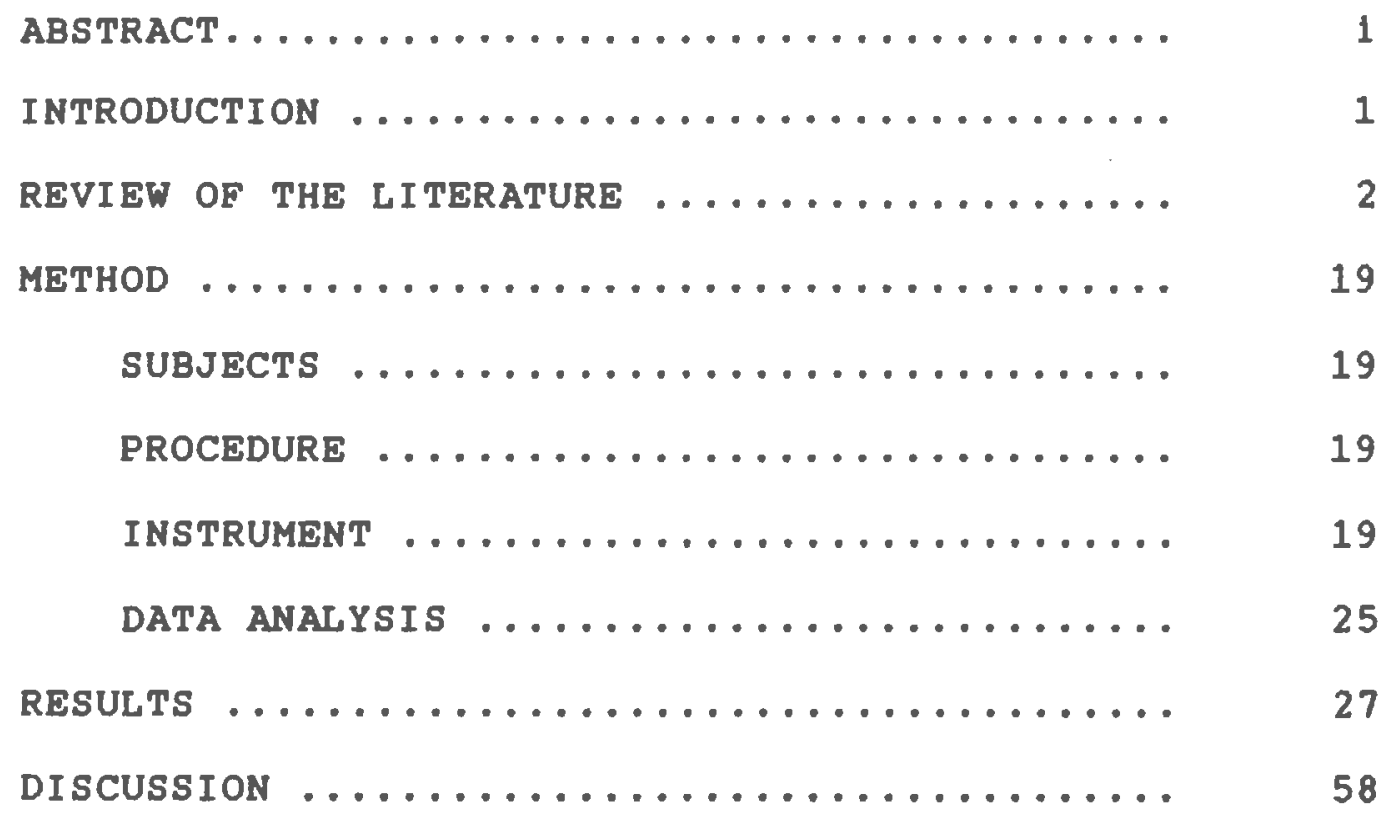


Page

Table 1 Percelved Anger to Three Levels of Instigations .................

Table 2 Perceptions of when it would be "all right" to get Angry ..........

Table 3 Frequencles of Perceived Bodily Responses to anger .............

Table 4 Anova Summary Table: Perception of Bod1ly Responses ................

Table 5 summary statistics for Number of Bodily Responses: age and sex ......

Table 6 Two classification schemes for organizing Children's Perceptions of Bodily Responses ................

Table 7 Constructive/Destructive Aspects: Three Open-Ended Questions ........

Table 8 Perceived Constructive/Destructive Outcomes: Age and $\operatorname{sex} . . . . . . . . .$.

Table 9 Percelved Constructive/Destructive Outcomes: By Target ..............

Table 10 Percelved Constructive/Destructive Outcomes: Age x Target ...........

Table 11 Percelved Construct1ve/Destructive Outcomes: Age $x \operatorname{sex} \ldots \ldots \ldots \ldots \ldots \ldots$

Table 12 Percelved Aggressive/Nonaggress Ive Outcomes: Age and sex ...........

Table 13 Percelved Aggressive/Nonaggressive Outcomes: Target Effects ..........

Table 14 Percelved Aggressive/Nonaggress Ive Outcomes: Age $x$ Target ...........

Table 15 Percelved Aggressive/Nonaggressive Outcomes: Age $x$ sex ............. 
Table 16 Perceived Aggressive/Nonaggressive

Outcomes: Sex x Target ........... 46

Table 17 Percelved Duration of Anger for seven

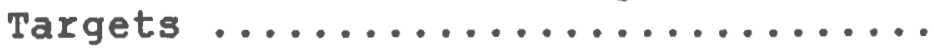

Table 18 Anova Summary Table: Perceptions of Duration of Anger .............. 50

Table 19 summary statistics for Duration:

Three Age Leve1s ................

Table 20 summary statistics for Duration:

Seven Targets .................

Table 21 summary statistics for Duration:

Age $x \operatorname{sex} \ldots \ldots \ldots \ldots \ldots \ldots . . . \ldots$

53

Table 22 summary statistics for Duration:

Age $x$ Target ..................

Table 23 Perceptions of Sex Differences in

Anger .......................

57 


\section{LIST OF FIGURES}

\section{Page}

Figure 1 Conceptions of the duration of anger as a function of age ............. 49 
CHILDREN'S CONCEPTIONS OF ANGER

For we are informed that during those years which have left nothing except a few incomprehensible memory fragments, we have vividly reacted to impressions, that we have manifested human pain and pleasure and that we have expressed love, jealousy and other passions as they then affected us. Indeed, we are told that we have uttered remarks which proved to grown-ups that we possessed understanding and a budding power of judgement. still we know nothing of all this when we become older. (sigmund Freud, 1962)

Introduction

Within the context of revived interest in the emotions there has been a steady increase in efforts almed at understanding the nature of their development. A review of the relevant literature reveals little work on actual "development" or changes the emotions may undergo over time. Much of the work tends to focus on the identification of a limited set of emotional states or expressive reactions in infants or very young children. There has been some emphasis in the most recent literature on children's knowledge of the meaning of various emotions and the effect of maturity on the chlld's grasp of concepts relating to different affects. But with the possible exception of a few obstensibly related behaviors (e.g., the development of fear or the smile response), we know little 
about chlldren's emotions. There remains a great need for increasing our knowledge of the precursors of individual emotions such as pride, anger, shame, and guilt.

An emotion which has received remarkably little attention both from a developmental perspective and in terms of its expression in adults is anger. In recent years a number of articles and several volumes have been generated by researchers interested in the adult experience of anger, but surprisingly the toplc of chlldren's anger has remained largely ignored. The idea for the present study arose with the realization that an important aspect of the child's development was not being addressed.

Review of the Literature

We know little about the development of anger. Goodenough's (1931) investigation of "angry outbursts" appears to be the only study to this point which has focused on the development of this emotion. Half a century later this analysis remains unique in its attempt to abstract from observations of children's "angry episodes" actual trends or changes in anger. From her investigation Goodenough (1931) concluded that the pattern of concerns or events associated with anger varled with the age of the child. She noted that in the younger child anger or "angry-like" responses seem to follow objections to simple physical routines or minor bodily discomforts. In contrast 
the older chlld beglns to displays his or her anger primarily in the context of problems of social relationships.

While such findings are intriguing and of obvious importance, Goodenough's (1931) study raises more questions than 1t answers. For example, the observations relied on a method whereby mothers, as raters, were instructed to record whatever appeared in the form of "anger", "rage", or even "marked 1rritation". Goodenough never attempted to define anger nor did she address the issue of the relationship among these various emotion terms or their connection to adult forms of anger. While a full discussion of the questions and concerns that could be ralsed here is beyond the scope of this paper, there is a bas1c Issue to consider: Is Goodenough's (1931) study about anger, or all "angry-like" responses? Is there any difference? other methodological difficulties exist. Goodenough constructed a classification scheme to order sources of anger. But the categorles developed were too broad to be theoretically useful in identifying developmental changes in the nature of the cause or provocation to anger (e.g., infants' screams following disappearance of the mother were subsumed under "problems of social relationships"). Despite these criticisms the study remains noteworthy for most investigators in this area tend to ignore possible changes in children's emotional 11 fe and focus instead on when these behaviors or 
feelings "emerge".

since the beginning of this century researchers have sought to identify "anger" in the expressions of infants and young chlldren. Watson (1919, 1929) for example, commented on the "rage reaction" of infants, and sherman (1927) tested Judges' abllity to discriminate a varlety of "emotional conditions" in newborns, lncluding anger. Much of the modern work in this area continues to focus on expressive reactions, measures of heart rate, gaze patterens, and other specific psychophyslological indices (Cf. Davidson, 1984; Izard \& Buechler, 1979; Zajonc \& Markus, 1984). In the fifty year span since Goodenough (1931) published her results, there has been no attempt to replicate her findings or suggest an alternate developmental course for anger. Research efforts continue to be directed towards the identification of a limited set of affects, such as fear or anxlety, and little time is devoted to development of such emotions as anger, pride, shame or guilt.

In part the lack of attention to questions of change is due to a common tendency to view emotions as things we have, as "essences" or Invariant cores that emerge preformed in the infant or young child. An assumption guiding the present investigation is that emotions are not static through the life span and that significant changes occur in the early years with the development of symbolic processes, language, a self-concept, and cognitive 
representations of rights and expectations. Consistent with this view of emotions as a dynamic, evolving phenomenon are a host of studies that have appeared in the past few years on children's understanding of emotion related concepts (e.g. Harris, Olthof, \& Terwogt, 1981; Masters \& Carlson, 1984; Welner \& Graham, 1984).

Some of these studies have found, for example, that as chlldren get older they are less likely to tie emotions to expressive reactions and will include in their discussion of the phenomenon a mental component (Harris et al., 1981). The older child is able to concelve of situations where one might experience two different emotions simultaneously, and situations in which emotions are masked by facial expressions or changed by redirection of thoughts (Trabasso \& Schwartz, 1984). Notwithstanding these advances in thinking about chlldren's emotions, there is still little information on the development of varlous affects. What is the relationship between the angry-like responses of the four month old infant and the experiences of anger in the adult? When do emotions such as pride and shame emerge? Do we need to posit, as some now argue, a stable sense of self and an ability to evaluate this "object" with respect to held standards before we can attribute such "self evaluative" emotions to children (Cf. Stipek, 1983)?

While there has been little attention focused on the issue of children's anger, it is interesting to note the horde of studies dealing with the closely related toplc of 
chlldhood aggression (e.g. Bandura, Ross, \& Ross, 1963; Eron, Walder, Huesmann, \& Lefkowitz, 1974; Slaby, 1974). There may be some good reasons for this preoccupation with aggression, having to do with real and percelved costs to soclety and the individual. But when anger and aggression are discussed together it is often to merely attribute the occurrence of the latter to the former. Anger becomes the "intervening variable" mediating between some stimulus event and an aggressive response. The problem with formulations of this kind is they discourage further study or understanding of anger or any other emotion, inserted solely for the purpose of linking other stimuli and responses.

Anger is important in 1ts own right. A great deal of violence is committed in the name of anger or excused after the fact by an appeal to anger (Aver1ll, 1979). The inablilty to express anger has also been implicated in a wide varlety of problems from depression to a host of psychophyslological disorders. How do children view their own anger and the anger of others? Are there aspects of the child's conceptions of anger that may be meaningfully related to childhood aggression? Not all anger leads to aggression and at times aggressive behaviors may proceed without anger. There is hope that a better understanding of the child's conception of anger will shed some light on these important questions. 
Focus of Present study

In the child we observe reactions of "rage" and the familiar "temper tantrums". What is the relationship between these events and the adult experience of anger? Are these early behaviors the precursors of the adult form? Are these fundamentally different phenomena or conversely do they reflect some invariant core that is merely canalized or channeled with age? Child theorists have speculated on these and related issues for some time. But aslde from Goodenough's (1931) early study little empirical work has been devoted to these questions. The present investigation hopes to address some of these issues in a cross-sectional study of children's conceptions of anger. The focus of this investigation will be on children's conceptions regarding various aspects of anger. Four parameters of anger, central to the human experience of this emotion will outline the study: the causes or instigations to anger, consequences, duration, and the physlological correlates or bodily feelings experienced during anger.

In addition, children's conceptions of sex-differences will be explored by asking chlldren whether they belleve boys and girls "get angry the same". It will be interesting to obtain some data in this regard since most 
of the adult work in this area has found few, if any, sexdifferences (Allen \& Hacoun, 1976; Aver111, 1982; Tavris, 19821 .

Each of these elements will be reviewed shortly along with relevant developmental hypotheses and some adult findings. But first, some mention of the sources from which the present approach is drawn is in order. Stated differently, the way in which anger will be examined here, in terms of causes, objects, etc., can be traced to a number of psychologists, past and present, who have used this approach to provide some valuable insights about the nature and meaning of emotion. A short discussion of these past investigations will provide a clearer point of departure.

\section{Previous "Structural Analyses"}

Some interesting and important analyses have proceded with the division of emotions into respective components or elements. Three lines of inquiry may be identified: philosophical treatments of anger and emotion, studies of anger in adults, and recent speculations on emotion developement. What follows is not a comprehensive review of these areas but rather a sampling of works by psychologists and philosophers who have used this approach in studying emotion. 
Ph1losophical Invest 1gat lons

In philosophical works on emotion a common strategy for arriving at explanations of these phenomena is to produce detalled accounts and descriptions of the structure of a certain feeling. Does the feeling have a typlcal object or target? What are the conditions that give rise to the emotion? How long does the experience typically last? Two examples, one drawn from antiquity and the other from a contemporary philosopher may serve to lilustrate this point.

Perhaps the most famous account of anger is the one found in Aristotle's Rhetoric (1966), which contains an elaborate discussion on "the causes of anger". A wide assortment of provocations known to elicit anger are listed here along with the reasons why it is these particular events that arouse us to this feeling. Aristotle also describes the likely targets of anger and their status and power relative to the angry subject.

"We are angry with those who have usually treated
us with honor or regard... and with those who
oppose us though they are our inferlors...and
with those who do not return our kindness or fall
to return this adequately... for by our hypothesis
the anger caused by the slight is felt towards
people who are not justified in slighting
us and our inferiors are thus not justifled."
(p. 1379 )

More recently, Robert solomon (1976), a philosopher interested in emotions and their relationship to values, put forth an "emotional register", a catalogue of sorts 
that presents each emotion in terms of its "direction", "object", "criteria", "status", "evaluations", and "responsibility". Note solomon's profile of anger:

Direction: Usually outer-directed, sometimes innnerdirected or bipolar (depending on the relative stress of the "offense" vs "my being offended").

object :

Always requires a responsible agent as 1 ts object. (even if it is anger at the weather, anger at a Jammed door, or anger at the termites devouring one's house).

Criter1a:

Usually have a moral edge, but may be personal as well (CE. INDIGNATION).

status:

Equal. (Cf. SCORN, RESENTMENT, CONTEMPT) .

Evaluations : Always a negative evaluation, an "offense".

Responsibility: Someone is blameworthy. (p. 264)

Anqer In Adults

The present investigation can also be viewed as an attempt to extend some of the work that has been done on the adult experlence of anger. of particular interest here is a serles of surveys by Aver1ll (1979, 1982) on the "everyday experlence of anger". Surveyed subjects were asked to respond to a variety of open-ended and forcedcholce questions concerning the objects of their anger, the duration of their angry experiences, the typical outcome etc. Some interesting findings emerged. Approximately ninety percent of the angry episodes were directed at human targets, over sixty percent involved close friends or 
aqualntances, and seventy percent of all the instances of anger were vlewed as "benefical" overall. More will be sald about these findings later. At this point the most important "finding" to note is that important aspects of anger were 11 luminated by the use of self report data.

Another interesting and relevant group of studies have focused on the reports of bodlly sensations, 1.e., the physlological feedback thought to occur in the process of an angry experlence. Two studles are particularly noteworthy: one by Gates (1926) and the other conducted by Davitz (1969). In both cases adult subjects were asked to consider a varlety of emotional experiences, including anger. Gates asked his subjects to keep dally records of their angry experiences for a one week period. In addition to information about eliciting condtions subjects were told to list the responses made. Gates was able to order these (over 300 responses) in terms of gross bodily movements (e.g. excited talking, sudden exit or refusal of food), expressive reactions (e.g. clenching teeth or hands), and a third class of activities dominated by the action of the sympathetic nervous system and the adrenal glands (e.g. rapid breathing, nausea, flushed skin). Davitz (1969) employed a slightly different method. He created a list of fifty emotion terms and asked subjects to recall instances in which they experienced these varlous feelings. After describing a specific incidence subjects read through a list of 566 items, checking off each item that 
characterlzed that particular experience.

There was not a great deal of overlap in the kinds of physlological reactions reported in the two studies. Davitz's subjects tended to emphasize cardiovascualr symptoms while those in Gates's Investigation reported more gastrointenstinal and respiratory changes. This was perhaps to be expected. Considerable varlabllity across studies and across subjects has been the norm in this area. Some theorists have used the divergent results to argue that obtained differences tell us more about individual differences or situational factors operating than about the actual nature of the emotion under study.

Research on Emotion Development

The mafor impetus for the present investigation has come from recent theorizing on the nature of emotion development. Many of the ideas in this area are the result of theorists interested in the social and affective implications of cognitive developmental changes. What follows is a brief review of some of these ldeas, presented in terms of the parameters to be used in this study.

Instigations to anger.

More than one theorist has offered the notion that instigations to anger may evidence some developmetal trend (Cf. Kagan, 1978; Plaget, 1960; Stipek, 1983). The 
clearest formulation may be found in Plaget's (1981) work on Intelligence and affectivity. He argues here that very young children will become emotional primarlly because of frustrations of simple physical routines or minor bodily discomforts. slightly older children of elght or nine are more likely to have feelings arising from attacks which threaten their developing self-concept. By the time a child is eleven or twelve, Plaget belleves he or she has the capacity to experience a varlety of emotions in response to less personal soclal violations, or transgressions that pertain to values and 1deals. (Note how this compares to Freud's (1962) vlew that ascrlbed a wide range of feelings to very young chlldren.) The present investigation will begin with this question: Can some agerelated trend be demonstrated for the instigations which lead to anger?

\section{objects or targets of anger.}

Another important aspect of anger, often discussed in phllosophical Investigations (CE. Lyons, 1980; Rorty, 1980), but typically ignored by psychologists, has to do with 1ts intentionality. Emotions have objects. One cannot simply be angry, proud, or ashamed in the abstract. There are obejcts connected to these feelings and these demonstrate a measure of appropriateness. One is not typically angry at the moon or jealous of the sun. But we may become angry at a friend, ashamed of ourselves, or 
proud of a son or daughter. What are the objects of children's anger? Do these exhibit the same degree of approprlateness? Do chlldren become angry at much older children? Arlstotle (1966) noted that as adults we typlcally do not become angry at those far superior to us or people who are vastly inferior; other emotions come into play. Will chlldren report anger at their parents or toward strangers? Historical teachings and recent studies Involving adults support the notion that objects of anger are predominately human. Do children reserve their angry feelings for humans? Wll they report anger at tables and chalrs or cats and dogs? These are interesting questions and while definitive answers will not be possible with a self report format, some important findings could emerge. Indeed a great deal about chlldren's experlence of anger might be learned from listening to a child explain why they do or do not become angry at a table or pet.

Consequences and duration.

As was noted earlier (Aver111, 1979, 1982), intervlews with. adults reveal that many instances of anger are viewed as beneflclal for both the angry person and the target. subjects will report continuing affective reactions following anger which are generally negative. But when asked to evaluate the overall harm or benefit of the episode, approximatley seventy percent of the subjects 
Indicate that "it helped to improve the situation" (Aver111, 1982).

Do children develop at some point, a notion that anger may help to improve things between people? This is a difficult question which invites the added complexities of "consclousness, unconsclousness", and "levels of processing." It seems safe to assume that very young children who are unable to reflect on emotional experiences or remember the causes or consequences would not be able to do much with questions of this $k$ ind. In contrast, the older chlld, according to Plaget $(1960)$, is on his or her way to better, fuller understanding of cause and effect relationships and may possess some conception of the consequences of anger and perhaps some awareness of it's utility.

The goal of this part of the study will be to evaluate notions that chlldren of varying ages have regarding the consequences and duration of anger. What do they belleve happens after one becomes angry? From their perspective what are the implications for the relationships in which an angry eplsode occurs? Once they have become angry, how long do they expect the feeling to last? Research with adults has shown considerable varlabllity in this regard, with responses ranging from "one or two hours" to "more than a day" (Fridhandler \& Aver111, 1982). Will children percelve differences in the duration of anger directed at different targets? 


\section{Bodlly reactions.}

Emotional experiences, instances of anger, fear, jealousy, etc., often engage a varlety of physiological responses. This aspect of children's anger may be the most difficult to tap and examine from a developmental perspective. We know little about chlldren's perceptions or experlences of their body and can only speculate on the ways in which they may come to associate emotional concepts with bodily changes.

Note that we typlcally speak of "feelings" in confuction with emotion as opposed to "sensations", which are more localized. This ldea is compatible with the adult self report data which argues against specific physlological reactions for the various emotions. In short there is little aggreement on the issue of bodily reactions and given that specific organs or systems cannot be rellably Identifled for anger and other emotions, one implication for child research is to focus on developing awareness of the body as a whole, as an object subject to change and disturbance.

Some very young children, when asked if they feel anything inside when angry, will retort "blood pressure" or "nerves". One may presume, perhaps correctly, that little understanding of relevant mechanisms is present in such chlldren. Over a hundred years ago G. Stanley Hall (1883) 
conducted a survey on "the contents of chlldren's minds'". Approximately two thousand Kindergarten children in the Boston area were interviewed and records were kept of the percentages of children who possessed certain concepts. Hall was careful to note the pattern of responses to certain questions.

\begin{abstract}
As to the physiological and geographical questions little need be sald. Joint, flesh, and veln are often unknown terms, or joint is where the bone is broken, and there are stones in the knee. Within the skin is blood and something hard, perhaps wood ....... psychic self consclousness is only of pain elther internal, as of stomache-ache, or peripheral as of cuts, bruises, etc." (p. 243)
\end{abstract}

statements children make about their body cannot be ignored. Behind the apparent absurdities lies the child's way of thinking about himself or herself and the world. A better understanding of their thought processes around these topics could help us in reconstructing their experience of bodily events. It is precisely the kind of data that may lead to a better understanding of the manner in which a child comes to connect various human encounters with abstract concepts such as anger and its associated bodlly reactions.

Children enter a world in which the meaning of actions and behaviors are prelabeled and where "emotion", in the largest sense, expresses the notion that something is happening to the body. For some philosophers the capacity 
to "experience" an event is intimately linked to our knowledge of labels for those events. Wittgenstein (1971) for example, wrote of the "expressivist" theory of meaning where certain terms express something about the object of reference (e.g. the physiological state of an individual).

It is tempting to point to the many upsets of childhood as providers, in a sense, of a range of physlological states (but perhaps not "experiences" strictly speaking). One could speculate that the acquisition of emotion labels handed down by parents and society in general play a critical role in establishing "emotional experiences". In any event if we seek to understand these kinds of processes, we will need to know more about children's knowledge of physlological concepts and what they belleve it means to be "emotional" or "angry". The above concerns will be addressed in a fourth phase of the study which asks children to consider whether "kids like them" feel particular things in their body during anger. Will children employ physiological concepts? How will age affect the degree of understanding of relevant mechanisms? 
METHOD

subjects

subjects will be sixty public school children; 10 boys and $10 \mathrm{glrls}$ each from grades one (6-7 yrs.), three (8-9 yrs.), and $\mathrm{six}(11-12$ yrs.).

\section{Procedure}

Following approval by the university's institutional review board, the experimentor sought the cooperation of principals or other designated school officials in the local elementary schools. Having achieved this, parental consent forms were distributed to teachers of grades one, three, and $s i x$.

Each chlld was intervlewed separately. The responses were recorded on answer sheets with no Identifying information. Chlldren were informed at the start about the nature of the study. They were told the purpose of the interview is simply to find out what makes kids angry.

\section{Instrument}

Backqround: Goals of The study And The "Clinical Method"

As mentioned earlier, traditional views of emotion 
presume some invariant core that potentially is observable at birth or shortly therafter. Within this framework the typical methods of research have involved lab based recordings of physiological events (e.g. heart rate or gaze pattern) or studies of expressive reactions (e.g. of the smile or during "fear conditons"). The assumptions guiding the present investigation are quite different. There is a shift in focus from ldentifying core aspects to the changes emotions may undergo as an individual matures. For this reason, physlological indices and expressive reactions will not be emphasized. Instead the study wlll concentrate on children's thoughts about anger, their conceptions about different aspects of this emotion. A special method is needed to access the child's thought processes in a systematic but unobtrusive manner.

Elkind (1964) notes that it was Plaget who first realized such questions require a method that combines two seemingly contradictory specifications: a process with enough flexiblilty to enable the researcher to follow the "meandering stream" of a particular child's thoughts, yet a technique with sufficlent standardization to cover the same ground with many chlldren of different age levels. Many researchers in this area now agree the combination of standard questions and free inquiry provided by the "semistructured interview" or the "clinical method" as some call it, is best suited for studies of children's thought processes. The method has its disadvantages, requiring 
much time for construction of the questions and analysis of the data. However the potential utility of this approach in studying the structure of thought may be unsurpassed.

\section{Construction of The Interview}

This section describes some of the considerations that went into the construction of the semistructured interview, and the process by which the above 1deas, hypotheses, and speculations were incorporated into this format isee Appendix A for a copy of the instrument). Before this is done some final comments on the use of self-report methods in studies of emotion may be warranted.

A great deal of controversy has centered on the "fruitfulness" of varlous methods of research in the area of emotion (CE. Mandler, 1979). Self-report measures have traditionally been attacked for their inablilty to get at "true determinants" of behavior. Critics inexorably appeal to distortions caused by "soclal desirability factors". Interviews are doomed they say, because the subject will inevitably rationalize any account of an emotional event. Mandler (1979) for one, has argued that self-reports may yleld the "contents". of emotional life but never the "underlying processes". The issues can become quite complex but we can always ask a simple question: What is the actual phenomena we are interested in? One can produce extreme rage reactions and anxiety states in the laboratory. Entire theories of emotion have been 
constructed around such "findings" although it is never made clear Just how such events relate to everyday experiences of anger, joy, pride, etc.

When Investigators outline aspects of an emotional experience, "objects", "causes", "consequences", etc., studies have shown that people respond with some Interesting and llluminating materlal. Adults and children may not know "how" or "why", strlctly speaklng, they become angry. If they are prompted in a structured way, however, they can discuss incidents in the past that made them angry, people who typically are the targets of their anger, the duration of the experience, etc. These are not trivial detalls, and whlle they may not directly reveal the socalled "underlying processes" of emotion, they may bring us closer to an understanding of such mechanisms than many of the "highly controlled" lab studies of fear, rage, aggression or pain.

In constructing the first part of the interview, dealing with Instigations to anger, an effort was made to present stimuli that would facilitate responding but remain to some extent free of "demand characteristics". Questions pertaining to each of the three categorles of instigations were developed (1.e., simple frustrations, attacks on the self-concept, and social or ethical transgressions). A total of nine questions were formulated (three for each level of Instigation). The situations were designed to be specific enough for children to identify but unstructured 
enough for them to bring in relevant issues, elaborations, or personal meanings that might shed further light on the manner in whlch children of varlous ages concelve of certain life events and how these interpretations affect their experlence of anger.

Before other segments of the interview are discussed, some general comments are in order. First, it was hypothesized that it might be less threatening to the children if:

1. Questions concerning instigations, targets of anger, etc. were prefaced by a statement concerning adult's reactions to such events. This is somewhat risky but on the other hand chlldren may balk unless they recelve, at some level, "permision" to acknowlege anger.

2. Children would not be asked if they personally could get angry under the specifled conditions. Rather they would be asked if "kids like them" could become angry.

Two common interview techniques, "slanting" and "countersuggestions", were employed. Subtle shifts in word order and minor additions or deletions (slanting) were used to avold the appearance of endless repetition. Countersuggestions were mixed into the preface statements regarding adult behavior (e.g. suggesting that many adults "never" get angry at $x$ or when $y$ occurs). A standard "why" 
or "why not" was added as a follow-up probe to all questions in the first three parts of the study (instigations, consequences, and duration). In part four, when the focus shifted to bodlly feelings during anger, childrens' responses were probed for degree of understanding of proposed mechanisms by asking them "how do you know?"

For purposes of developing a more comprehensive view of childrens' conceptions of instigations to anger, an open-ended question was also included. Chlldren were asked "when would it be alright to get angry?" This was added to provide some index of the kinds of instigations chlldren of varying ages would spontaneously generate.

Little is known about children's expectations following an experlence of anger. It may be difficult for chlldren to understand the eplsodic nature of anger and other emotions, or they may fall to realize that at times their anger is Justified and may, not result in punishment or retribution. Questions such as these, relating to the consequences of anger were addressed in part two of the instrument with a series of inquiries organized around seven different potential targets of anger (siblings, parents, teachers, friends, strangers, pets, and tables and chalrs). Chlldren were asked if "kids like them" -would become angry at $x$, and if so, "what happens after ?" In order to tap children's conceptions of the duration of anger, chlldren were also asked "how long" would they 
(k1ds like them) stay angry. In the few instances where the chlld falled to ackowledege anger towards a particular target, the intervlewer asked the chlld to "pretend" that "a kid like you became angry" at $x$.

Three open-ended questions were also included in this section. Children were asked 1) "1s it good or bad to get angry?" 2) "what are some bad ways to show you are angry?", and 3) "what are some good ways to show you are angry?" Again the purpose of these open-ended questions was to generate a more comprehensive vlew of a child's conceptions about a particular aspect of anger.

The fourth phase of the interview attempted to probe children's conceptions of what may be going on inside their body when they become angry. As already mentioned the real concern in this part of the study was not the specific organs or systems chlldren propose, but their ability to connect physlological events with emotions like anger.

Finally, to Investigate perceptions of sex-differences among chlldren of different ages, all subjects were asked whether they belleved boys and girls got angry the same, and why.

Data analysis

Most of the data is categorical and involves Chi square procedures on the frequencles generated within each level of instigation, type of consequence (e.g. 
constructive vs desstructive), etc. Frequency comparisons are made across age, sex, and target.

An ANOVA procedure was used to analyze age, sex, and target differences in chlldren's perceptions of the duration of anger. Tlme in hours served as the dependent measure.

A comblnation of procedures was used to analyze perceptions of bodlly response. Categorles of bodlly reactions are examined with ChI square procedures but an ANOVA was used to examine age, sex, and target differences in number of bodily reponses reported. 


\section{RESULTS}

The results which follow are analyzed mainly on the basis of nonparametric statistics. Although this is partly due to the small sample size $(n=30)$ it is also a function of the methods used. The semistructured interview ylelds a wealth of data that is usefully organized into categorles. Two exceptions to this are: 1) all the data concerning chlldren's conceptions of the duration of anger, and 2) parts of the results having to do with children's conceptions of bodily responses to anger. It was possible to represent "duration" in a continous fashion by converting all reponse times into hours. These results were analyzed with a repeated measures ANOVA design to examine age, sex, and target effects, and possible interactions involving these variables. A similar approach was taken to compare number of (reported) bodily responses across age levels. A one-way ANOVA procedure was used with number of bodily reactions concelved by each child serving as the dependent measure. The results are presented in the following order; 1) instigations to anger, 2) bodily responses during anger, 3) consequences of anger, 4) duration of anger, 5) conceptions of sex differences. These will be revlewed separately, then summarized, and ultimately discussed. 
Instigations To Anger

As noted earlier the issue of instigations to anger was approached from two directions. A series of semistructured questions, located in three levels of Instigations (simple frustrations, attacks on the self, social violations) were used to test a series of interelated hypotheses. The results of this approach is reviewed first. This is followed by a second open-ended exploration into this issue.

Table 1

Percelved Anger to Three Levels of Instigations

$\begin{array}{lccccc}\text { level } & \begin{array}{c}6-7 \\ \text { yes/no }\end{array} & \begin{array}{c}8-9 \\ \text { yes/no }\end{array} & \begin{array}{c}11-12 \\ \text { yes/no }\end{array} & \text { x2(2) } & \text { P } \\ \text { simple } & 20 / 10 & 26 / 4 & 27 / 3 & 6.23 & <.05 \\ \text { self } & 15 / 15 & 24 / 6 & 28 / 2 & 15.33 & <.05 \\ \text { social } & 18 / 12 & 11 / 19 & 14 / 16 & 3.29 & \mathrm{~ns} \\ & & & \end{array}$

Table 1 presents the results of a Ch1 square analysis of chlldren's responses to the three levels of instigations. At the level of simple frustrations rlevel I) no age differences were expected. It was hypothesized that children of all ages would perceive the liklihood of anger to such instigations. As can be seen from table 1 
there was a slgniflcant difference across age levels. A follow-up analysis revealed the youngest chlldren (6-7) were less likely to perceive anger to such frustrations than were elther of the two older groups: $\times 2(1)=6.11$, p < .05 . There were no significant sex differences.

It was hypothesized that age differences would begin to emerge at level 2 (attacks upon the self), and that with age, more anger would be percelved to result from such Instlgations. speciflcally, it was expected that 8-9 year old chlldren would percelve signiflcantly more anger than children 6-7 years of age. The results from table 1 support this notion. A significant difference was found across age levels. A follow-up analysis testing the a priori assumption of discontinuity between the 6-7 year olds and the 8-9 year olds was statistically slgnificant: $\mathrm{X} 2(2)=13.97, \mathrm{p}<.05$. The results demonstrate that $8-9$ year old chlldren were more likely to percelve anger in conjunction with self-esteem issues.

The highest level of instigations (level 3), involving social or moral transgressions, was expected to yleld the most dramatic age differences. It was hypthesized that the oldest group, the 11-12 year old chlldren, would be significantly more likely to percelve anger to result from such instigations. The results from table 1 do not support this contention. The differences across age levels were not statistically significant. 


\section{Open-Ended Inquiry}

A second approach to the instigation issue involved an open-ended inquiry which asked children to consider "when would it be all right to get angry?" The hypothesis being tested here was that older children would be more likely to bring in concepts of "rule violations" of an interpersonal, social, or ethical nature. The results, which appear below in table 2, support this hypothesis. When children's responses to this question were categorized, two major classes of instigations emerged, one involving the subject as a target of aggression, and the second portraying the target of anger as one who had "violated" some rule of Interpersonal, social, or ethical conduct (e.g., was responsible for an unjustified or nonaccidental assault or a social violation such as littering). As table 2 demonstrates there was a significant age difference with respect to these two broad classes of instigations. A follow-up analysis revealed that it was significantly more likely for the older children, ages 8-9 and 11-12, to bring in concepts of rule violations than the youngest children, aged 6-7: $\times 2(2)=5.1, P<.05$. 
Table 2

Perceptions of When It Would Be "All Right" To Get Angry"

\begin{tabular}{l} 
target of \\
$\begin{array}{l}\text { aggression } \\
\text { rule }\end{array}$ \\
violation \\
\hdashline$\quad 0$ \\
$x 2(2)=6.32$, p $<.05$
\end{tabular}

Bod11y responses

Two hypotheses were advanced with respect to children's perceptions of bodlly responses during anger. First, it was hypotheslzed that at all age levels no strong agreement would emerge with respect to any particular body part, organ, or system. secondly, it was hypothesized that the older chlldren would report, on the average, a greater number of potential bodily responses during anger. In table 3 the frequencles of varlous bodily responses thought to occur during anger are presented. In support of hypothesis I, it can be seen that no particular body part, organ or system appears to predominate in children's conceptions. 
Table 3

Frequencies of Perceived Bodily Responses In Anger

\begin{tabular}{|c|c|c|c|c|c|}
\hline $6-7$ & & $8-9$ & & $11-12$ & \\
\hline $\begin{array}{l}\text { headache } \\
\text { heart } \\
\text { lungs } \\
\text { stomach } \\
\text { shaky } \\
\text { don't } \\
\text { know }\end{array}$ & $\begin{array}{l}3 \\
3 \\
1 \\
1 \\
1 \\
1\end{array}$ & $\begin{array}{l}\text { stomach } \\
\text { headache } \\
\text { heart } \\
\text { face } \\
\text { throat } \\
\text { back } \\
\text { flngers } \\
\text { pulse } \\
\text { nerves }\end{array}$ & $\begin{array}{l}5 \\
4 \\
3 \\
1 \\
1 \\
1 \\
1 \\
1 \\
1\end{array}$ & $\begin{array}{l}\text { tightness } \\
\text { headache } \\
\text { stiffness } \\
\text { stomach } \\
\text { nerves } \\
\text { heart } \\
\text { face } \\
\text { "bodily } \\
\text { functions" }\end{array}$ & $\begin{array}{l}6 \\
5 \\
4 \\
3 \\
3 \\
1 \\
1 \\
1\end{array}$ \\
\hline
\end{tabular}

The second hypothesis involves a comparison of the different age groups with respect to number of (percelved) distinct bodily reponses in anger. The notion that it would be easier for older chlldren to conceptualize different bodily reactions in anger was tested with a $3 \times 2$ (age $x$ sex) ANOVA procedure with number of reported bodily reactions serving as the dependent measure. The results are summarized below in table 4.

Table 1

Anova Summary Table: Perceptions of Bod1ly Responses

\begin{tabular}{lrrrrr} 
Source & SS & df & Ms & & \\
age (a) & 10.70 & 2 & 5.35 & $8.02 *$ & .305 \\
sex (b) & 2.70 & 1 & 2.70 & $4.05 *$ & .066 \\
ab & .60 & 2 & .30 & .45 & \\
error & 16.00 & 24 & .67 & & \\
\hdashline * $<.05$ & & & &
\end{tabular}


There were signiflcant maln effects for age and sex. Table 5 displays the means and standard deviations for the three age groups and both sexes. As a group, females reported significantly more bodily reactions than males. A Newman-Keuls post hoc means comparison procedure was performed on the three age groups to isolate the slgnificant differences. The results revealed the youngest group of children, ages 6-7, reported significantly fewer bodily reactions than elther of the two older groups. The 8-9 and 11-12 year old groups were not significantly different.

Table 5

Summary Statistics For Number of Bodily Reactions Percelved: Age And Sex

Age
$6-7$
1.00
.63
$8-9$
1.90
1.06
11-12
2.40
.74

Sex
males
1.46
.89

females

2.06

.99 
Table 6 illustrates that it was possible to classify children's responses in two additional ways: a division into specific and nonspecific bodily reactions that separated distinct parts, organs, or systems from global feelings of tension or tightness, and a tripartite classification that highlighted somatic complaints, nervous system responses, and feelings of stiffness or tightness.

Table 6

Two Classification Schemes For Organizing Children's Perceptions of Bodlly Responses

\begin{tabular}{|c|c|c|c|}
\hline specific/nonspecific & $6-7$ & $8-9$ & $11-12$ \\
\hline specific & 9 & 19 & 13 \\
\hline nonspecific & 1 & 0 & 11 \\
\hline$\times 2(2)=13.69, p<.05$ & & & \\
\hline $\begin{array}{l}\text { II nervous system/pain/ } \\
\text { stiffness or tightness }\end{array}$ & $6-7$ & $8-9$ & $11-12$ \\
\hline $\begin{array}{l}\text { nervous system } \\
\text { pain } \\
\text { stiff/tight }\end{array}$ & $\begin{array}{l}4 \\
4 \\
0\end{array}$ & $\begin{array}{r}5 \\
14 \\
0\end{array}$ & $\begin{array}{r}5 \\
10 \\
10\end{array}$ \\
\hline
\end{tabular}

The analysis of specific vs. nonspecific responses across age levels presented in rable 6 shows a significant age difference. A follow-up analysis revealed that the oldest group of children (11-12) were signiflcantly more likely to percelve nonspecific bodily responses than were 
e1ther of the two younger groups: $x 2(1)=13.32, P<.001$. The results of the analysis using the tripartite system (nervous system, pain, stiff/tight) also presented in Table 6, show a significant effect for age. A followup analysis revealed that children in the oldest group (1112) were significantly more likely to perceive a resulting stiffness or tightness during anger than were elther of the two younger groups: $\times 2(1)=5.22, P<.05 .$, and that chlldren in the 8-9 year old group were signiflcantly more likely to perceive a resulting pain or somatic complaint when angry than chlldren in either of the other two age groups: $\times 2(1)=5.55, P<.05$.

\section{Consequences of Anger}

The results pertaining to consequences of anger focus on two related but divisible potential outcomes of anger. These are the constructive/destructive distinction and the aggressive-nonaggressive dichotomy. The issue of perceived constructive or destructive consequences of anger was approached from two directions. A series of open-ended questions tested the hypothesis that older children would be more capable of percelving constructive outcomes arising from anger. As table 7 demonstrates, there were no significant age differences with respect to the first question in this series "Is it good or bad to get angry?". There was overwhelming consensus that it was good to get 
angry. A simllar finding occurred in response to the question "What are some bad ways to show you are angry?". Most children at all three age levels were able to generate a response to this question. In contrast to these findings, the third question, "What are some good ways to show you are angry?", produced dramatic age differences. A follow-up analysis revealed that the youngest group $(6-7)$ was significantly less likely to provide a response to this question: $\mathrm{X} 2(1)=10.76, \mathrm{P}<.05$.

Table 7

Constructive/Destructive Aspects: Three Open-Ended Questions

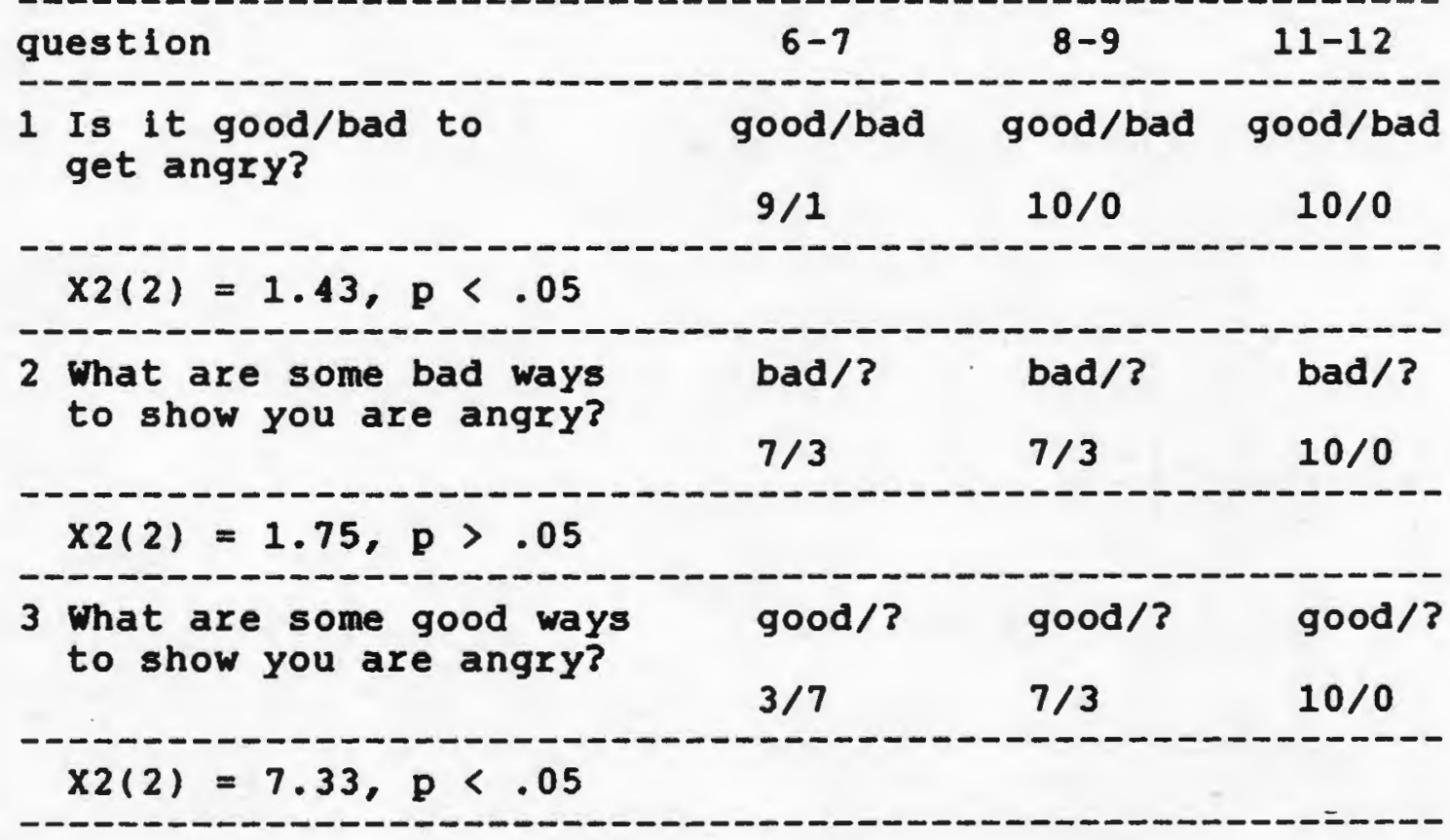




\section{structured Approach}

A more structured approach to this issue brought in specific targets of anger. Children's responses to the question "what happens after" were grouped into two categories: "constructive" and "destructive". The former Included such outcomes as "making up", and "reporting" the offense. The latter embraced such consequences as "hitting" (the target of anger), or "punishment" (typlcally received by the angry subject who has become angry at a superior). Two independent raters were able to classify the children's responses with a high degree of rellability: $r=.90$.

Table 8 reveals there were nonsignificant differences across age levels, and between sexes. As can be seen approximately 408 of the outcomes perceived by children were constructive while 608 were destructive. 
Table 8

Percelved Constructive/Destructive outcomes: age and sex

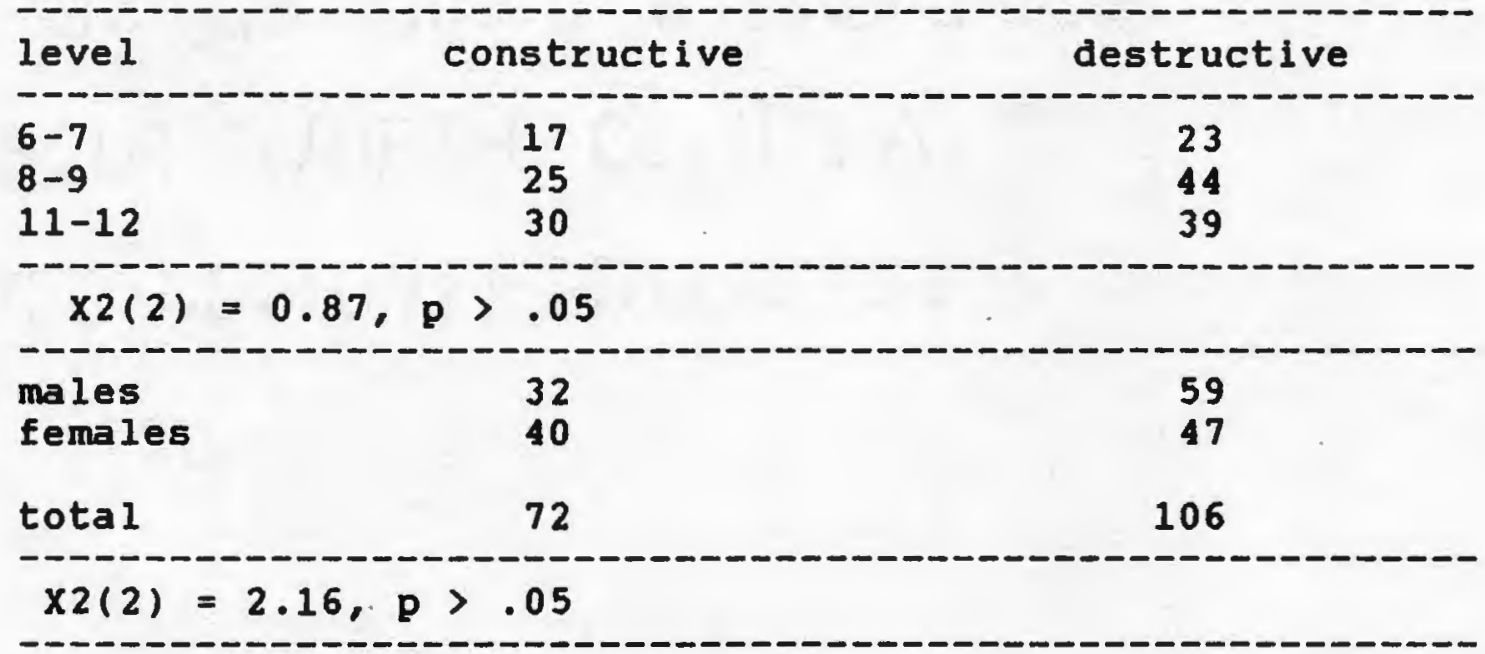

\section{Target Effects}

In Table 9 the results show a significant difference across the seven targets of anger. The follow-up analyses revealed that children were significantly more likely to percelve destructive consequences of anger when the target was a teacher than when it was a stranger: $X 2(1)=15.00$, $p$ $<.05$, a pet: $\times 2(1)=14.68, \mathrm{p}<.05$, a frlend: $\times 2(1)=$ 10.91, $p<.05$, one's mother or father: $\times 2(1)=4.48, p<$ .05 , or a slbling: $\times 2(1)=4.48, p<.05$. Chlldren were significantly less likely to perceive destructive consequences of anger when the target was a stranger as compared to a parent: $\quad x 2(1)=6.42, p<.05 .$, a sibling: $\times 2(1)=6.42, p<.05$, or a table or chair: $\times 2(1)=7.76, p$ 
$<.05$. But Chlldren were signiflcantly more likely to perceive destructive consequences of anger when the target was a table or chair in comparison to a pet: $\times 2(1)=4.69$, $\mathrm{p}<.05$.

Table 9

Perceived Constructive/Destructive outcomes: By Target

\begin{tabular}{|c|c|c|}
\hline Target & constructive & destructive \\
\hline $\begin{array}{l}\text { frlend } \\
\text { mother and father } \\
\text { brother or slster } \\
\text { teacher } \\
\text { stranger } \\
\text { pet } \\
\text { table/chair }\end{array}$ & $\begin{array}{r}13 \\
8 \\
8 \\
2 \\
16 \\
15 \\
6\end{array}$ & $\begin{array}{r}15 \\
18 \\
18 \\
24 \\
8 \\
11 \\
17\end{array}$ \\
\hline
\end{tabular}

Age By Tarqet

In table 10, perceptions of constructive vs. destructive consequences of anger are shown for each of the three age groups across the seven targets. There were no significant target differences for either the 6-7 year old group, or the 11-12 year old group. But significant differences were seen at the 8-9 year old level. A follow up analysis revealed that children at this age level were significantly less likely to perceive destructive conseguences of anger when the target was a stranger than when it was a teacher: $\quad X_{2}(1)=13.32, \mathrm{p}<.05$, a sibling: 
$\mathrm{X} 2(1)=7.2, \mathrm{p}<.05, \mathrm{a}$ table/cha1r: $\times 2(1)=6.33, \mathrm{p}<.05$, or a friend: $X 2(1)=5.02, P<.05$. Children in this age range were also significantly more likely to perceive destructive consequences of anger when the target was a teacher than when it was a pet: $\times 2(1)=8.56, p<.05$, or a parent: $x 2(1)=5.00, p<.05$.

Table 10

Perceived Constructive/Destructive outcomes: Age x Tarqet

\begin{tabular}{lccc} 
Target & $6-7$ & $8-9$ & $11-12$ \\
& $c / d$ & $c / d$ & $c / d$ \\
\hline friend & $7 / 1$ & $3 / 7$ & $3 / 7$ \\
mother/father & $1 / 5$ & $4 / 6$ & $3 / 7$ \\
brother/sister & $1 / 5$ & $2 / 8$ & $1 / 6$ \\
teacher & $1 / 5$ & $0 / 10$ & $7 / 3$ \\
stranger & $1 / 3$ & $8 / 2$ & $5 / 5$ \\
pet & $4 / 2$ & $2 / 7$ & $5 / 4$ \\
table/chair & $2 / 3$ & 18.56 & 9.51 \\
\hline x2(6) & 11.93 & .05 & .10 \\
\hline p & .08 & 05 & -
\end{tabular}

Age By Sex Effects

Table. 11 displays the age $x$ sex results. As can be seen there were no slgniflcant sex differences for the 6-7 year old chlldren, or the 8-9 year old group. However there was a significant difference between males and females at the 11-12 year old level, with males showing a greater tendency to percelve distructive consequences. 
The sex $x$ object interaction was not signlficant.

Table 11

Percelved Constructive/Destructive outcomes: Age x Sex

\begin{tabular}{lccc} 
& $6-7$ & $8-9$ & $11-12$ \\
males & $c / d$ & $c / d$ & $c / d$ \\
females & $8 / 13$ & $14 / 21$ & $10 / 25$ \\
\hdashline$\times 2(1)=$ & $9 / 10$ & $11 / 23$ & $20 / 14$ \\
$\mathrm{p}=$ & 1.28 & .40 & 6.42 \\
\hline & $\mathrm{ns}$ & $\mathrm{ns}$ & $<.05$
\end{tabular}

\section{Aggression}

Chlldren's responses to the question of "what happens after" were also classifled as aggressive or nonaggressive. The latter included such outcomes as "leaving" the situation or "reporting" the offense, whlle the former Involved behaviors such as "hitting" or "punching" the instigator. Two Independent raters were able to rellably classify children's responses in this fashion: $r=.90$. In Table 12 the results of this classification scheme are displayed with respect to overall age and sex differences. As can be seen, there were no signiflcant age differences. But there were signiflcant sex differences, with males showing a greater tendency to percelve aggressive outcomes. 
Table 12

Percelved Agaressive/Nonaggressive Outcomes: Age and Sex

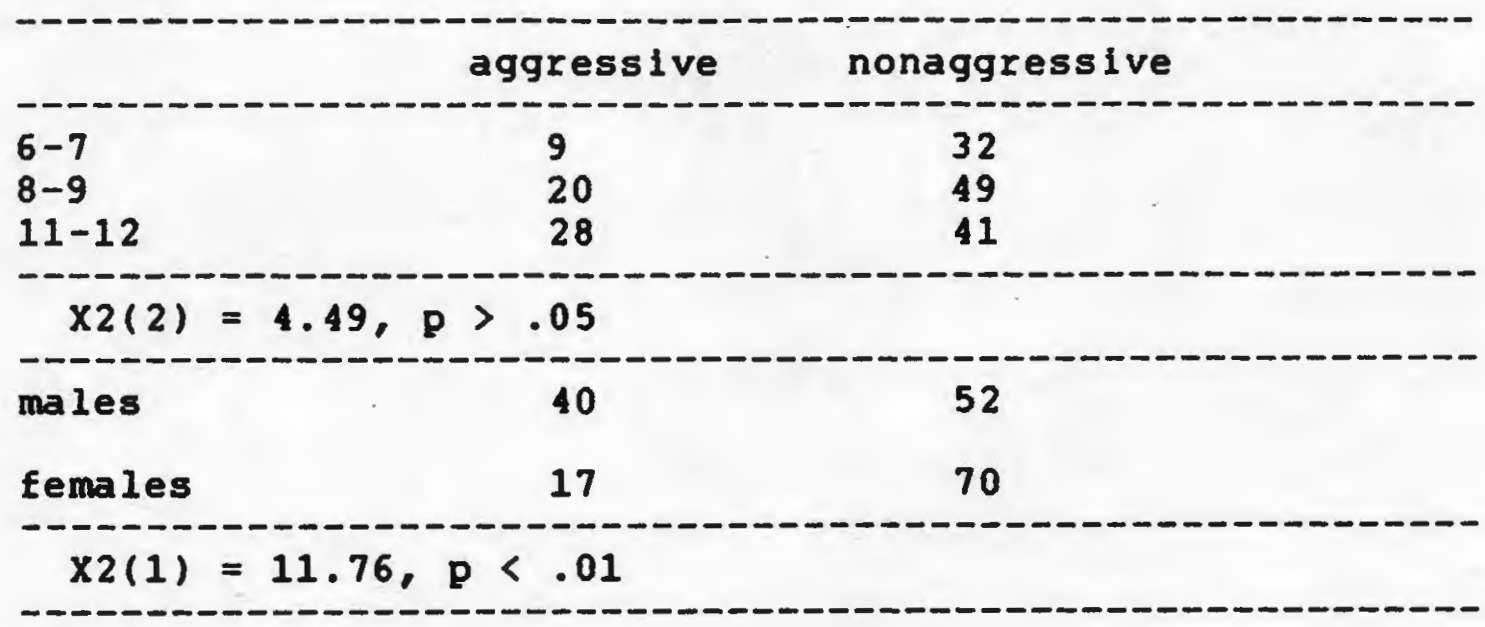

\section{Target Effects}

Table 13 illustrates the impact of various targets on children's conceptions of aggressive vs. nonaggressive outcomes for anger. As this shows there was a signiflacant overall difference across targets. The follow up analyses revealed that when the target of anger was a parent children were signiflcantly less likely to percelve an aggressive outcome than when it was a table or chalr: $\times 2(1)$ $=22.47, \mathrm{p}<.01, \mathrm{a}$ slbling: $\times 2(1)=6.93, \mathrm{p}<.01$, a pet: $X 2(1)=6.93, p<.01$, or a frlend: $X 2(1)=5.02, p<.05$. In addition, if the target was an inanimate object, a table or chalr, children were significantly more likely to perceive an aggressive consequence than if it were a stranger: $X 2(1)=15.61, \mathrm{p}<.01$, a teacher: $\mathrm{X2}(1)=12.64$, $p<.01$, a frlend: $x 2(1)=8.8, p<.01$, a s1bling: $\times 2(1)=$ 
$6.18, \mathrm{p}<.05$, or even a pet: $\times 2(1)=6.18, \mathrm{p}<.05$.

Table 13

Percelved Aggressive/Nonaggressive Outcome: Target Effects

\begin{tabular}{|c|c|c|}
\hline target & aggressive & nonaggress I ve \\
\hline $\begin{array}{l}\text { frlend } \\
\text { mother/father } \\
\text { brother/sister } \\
\text { teacher } \\
\text { stranger } \\
\text { pet } \\
\text { table/chair }\end{array}$ & $\begin{array}{r}9 \\
2 \\
10 \\
6 \\
4 \\
10 \\
17\end{array}$ & $\begin{array}{r}19 \\
24 \\
16 \\
20 \\
20 \\
16 \\
6\end{array}$ \\
\hline
\end{tabular}

Age By Target

The age $x$ target effects are displayed in table 14. This demonstrates a lack of significant differences across targets for both the 6-7 year old children and the 11-12 year old chlldren. However, there were signiflcant target differences among children 8-9 years of age. The follow up analyses revealed that when the target of anger was a stranger, children ages 8-9, were significantly less likely to percelve an aggressive outcome than when the target was a table or chalr: $\times 2(1)=12.88, p<.05$, or a sibling: $\times 2(1)=6.66, p<.05$. But if the target was an inanimate object, a table or chair, children in this age range were significantly more likely to perceive an aggressive consequence than if it was a parent: $X 2(1)=11.65, \mathrm{p}<$ 
.01 , a teacher: $\times 2(1)=6.32, \mathrm{p}<.05$, a frlend: $\times 2(1)=$ $6.32, \mathrm{p}<.05$, or a pet: $\times 2(1)=4.32, \mathrm{p}<.05$.

Table 14

Perceived Aggressive/Nonaggressive Outcomes: Age x Target

\begin{tabular}{|c|c|c|c|}
\hline target & $\begin{array}{l}6-7 \\
a / \text { na }\end{array}$ & $\begin{array}{r}8-9 \\
a / n a\end{array}$ & $\begin{array}{l}11-12 \\
\mathrm{a} / \mathrm{na}\end{array}$ \\
\hline $\begin{array}{l}\text { friend } \\
\text { mother/father } \\
\text { brother/sister } \\
\text { teacher } \\
\text { stranger } \\
\text { pet } \\
\text { table/chair }\end{array}$ & $\begin{array}{l}1 / 7 \\
0 / 6 \\
1 / 5 \\
0 / 6 \\
2 / 2 \\
2 / 4 \\
3 / 2\end{array}$ & $\begin{array}{r}2 / 8 \\
1 / 9 \\
5 / 5 \\
2 / 8 \\
0 / 10 \\
3 / 7 \\
7 / 2\end{array}$ & $\begin{array}{r}3 / 5 \\
0 / 10 \\
4 / 6 \\
4 / 6 \\
3 / 7 \\
5 / 5 \\
7 / 2\end{array}$ \\
\hline$x 2(6)=$ & 10.7 & 22.04 & 7.9 \\
\hline$p=$ & $<.05$ & $<.05$ & ns \\
\hline
\end{tabular}

\section{Sex Differences}

There were significant sex differences for two of the three age groups. As table 15 indicates there were no significant differences among males and females at the 6-7 year level. But among the 8-9 year old children, and the 11-12 year old chlldren there were signiflcant sex differences, with males in both age groups showing a greater tendency to percelve aggressive outcomes. 
Table 15

Percelved Aggressive/Nonaggressive Outcomes: Age x Sex

\begin{tabular}{lccc} 
sex & $6-7$ & $8-9$ & $11-12$ \\
& $\mathrm{a} / \mathrm{na}$ & $\mathrm{a} / \mathrm{na}$ & $\mathrm{a} / \mathrm{na}$ \\
males & $6 / 16$ & $14 / 21$ & $20 / 15$ \\
females & $3 / 16$ & $6 / 28$ & $8 / 26$ \\
\hdashline $\mathrm{n}(1)=$ & .76 & 4.17 & 7.67 \\
\hdashline $\mathrm{p}=$ & $\mathrm{ns}$ & $<.05$ & $<.05$ \\
\hline
\end{tabular}

Sex By Target

In table 16 the influence of different targets on children's perceptions of aggressive vs. nonaggressive outcomes is presented. Only two of the seven targets evoked significantly different frequencles of percelved aggressive and nonaggressive outcomes by males and females. These were frlends and tables/chalrs. For both targets, there was a greater tendency on the part of males to percelve aggressive consequences. 
Table 16

Perceived Aggressive/Nonaggressive outcomes: Sex By Target

$\begin{array}{lcccc} & \text { males } & \text { females } & \times 2(1) & \text { p } \\ \text { Target } & 8 / 7 & 0 / 13 & 9.61 & <.05 \\ \text { Eriend } & 1 / 12 & 0 / 13 & 0.00 & \mathrm{~ns} \\ \text { mother/father } & 7 / 8 & 4 / 7 & 0.26 & \mathrm{~ns} \\ \text { brother/sister } & 4 / 9 & 2 / 11 & 1.09 & <.05 \\ \text { teacher } & 3 / 9 & 2 / 10 & 0.00 & \mathrm{~ns} \\ \text { stranger } & 5 / 6 & 5 / 10 & 0.00 & \mathrm{~ns} \\ \text { pet } & 12 / 1 & 5 / 5 & 5.25 & <.05 \\ \text { table/chair } & & & \end{array}$

\section{Duration of Anger}

Table 17 displays chlldren's conperceptions of the duration of anger for each of the seven targets. As can be seen, most of the "eplsodes" are conceptualized in terms of hours with both the 6-7 and 8-9 year old children expecting the angry state to last an average of approximately ten hours. The 11-12 year old children percelved much longer experiences of anger, averaging nearly thirty hours. 
Table 17

Percelved Duration of Anger For Seven Targets

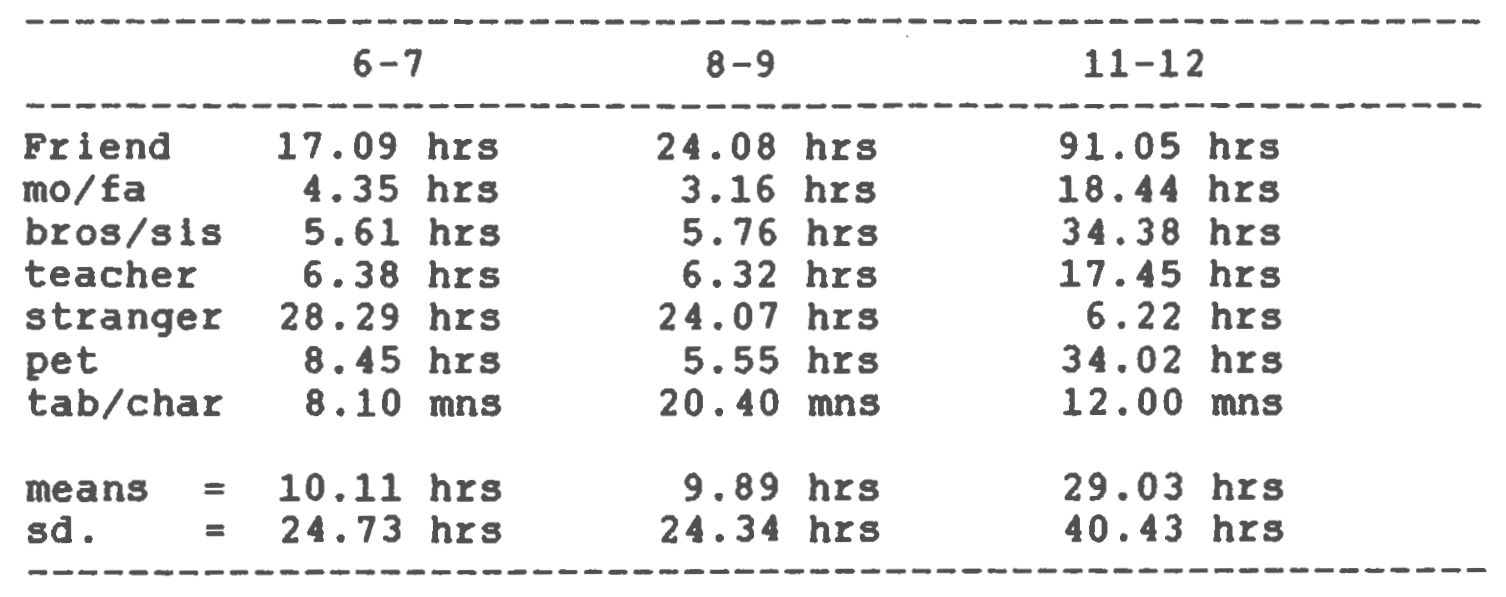

Figure 1 111ustrates the age trend for each of the seven targets. The critical aspect to note here is the Increased separation and clustering of responses for the varlous targets which suggests greater discrimination among the older children. 
Fiqure 1 . Conceptions of the duration of anger as a function of age. 


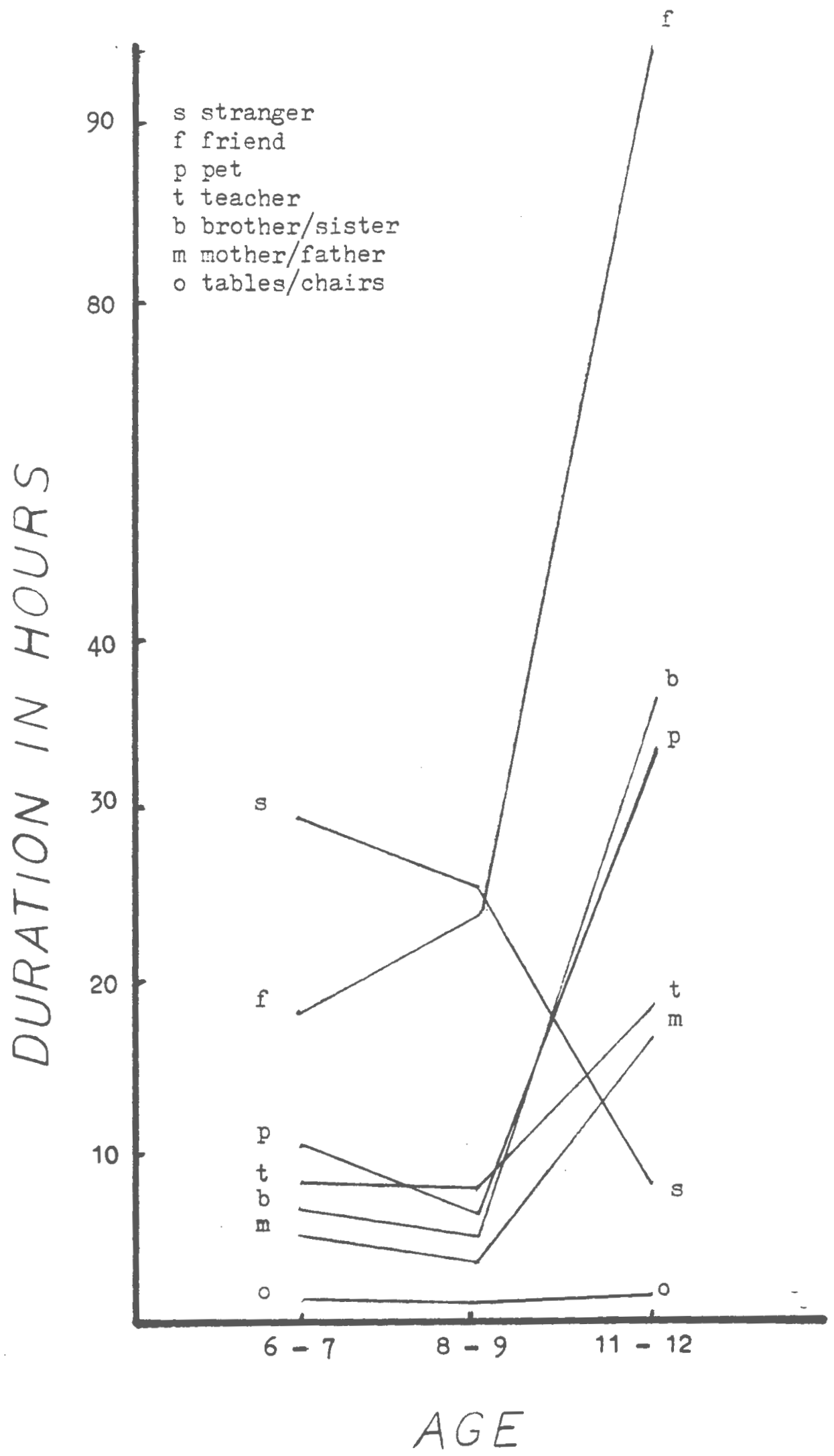


Children's conceptions of anger's duration was expected to vary as a function of age and the particular target. It was hypothesized that older children would report longer episodes of anger, but that all children would perceive differences in the length of time one would remain angry at various targets. To test these hypotheses a $3 \times 2 \times 7$ (age $\times$ sex $\times$ target) repeated measures ANOVA was performed with time in hours serving as the dependent measure. The results are summarized below in table 18 .

Table 18

Anova Summary Table: Perceptions of Duration of Anger

\begin{tabular}{lrrrrc} 
Source & \multicolumn{1}{c}{ SS } & df & MS & F & W \\
\hline Age (A) & 16886.86 & 2 & 8443.43 & $8.15 * *$ & .07 \\
Sex (S) & 35.58 & 1 & 35.58 & 0.03 & \\
AS & 8454.87 & 2 & 4227.43 & $4.08 *$ & .03 \\
Error & 24850.19 & 24 & 1035.42 & & \\
Target (T) & 34446.47 & 6 & 5741.07 & $10.31 * *$ & .14 \\
AT & 32740.83 & 12 & 2728.40 & $4.90 *$ & .12 \\
AS & 2495.48 & 6 & 416.08 & 0.79 & \\
AST & 12715.83 & 12 & 1059.65 & 1.90 & \\
Error & 80161.18 & 144 & 556.67 & & \\
\hline
\end{tabular}

As this shows there were significant main effects for age and target. The main effect for sex was not statistically significant. TAble 19 contains the means and standard deviations for the various age groups. A Newman-Keuls post hoc comparison procedure was conducted on the totals for the three age groups. The 11-12 year old 
chlidren's perceptions of anger's duration was significantly longer than either of the two younger groups. The perceptions of duration of the 6-7 and 8-9 year old children were not significantly different.

Table 19

Summary Stat1stics For Duration: Three Age Groups

MN

10.11

9.90

29.03 sd

24.73

24.34

11-12

40.43

In table 20 the summary statistics for the seven targets of anger are presented. A Newman-Keuls procedure performed on the seven targets revealed that most of the differences involved the "friend" target. Children percelved an episode of anger directed at a friend to be significantly longer than an experience of anger involving any of the $s i x$ other targets. The one other difference which emerged involved tables and chalrs versus strangers. Children perceived an angry episode directed at a stranger to be significantly longer than one directed toward an inanimate object like a table or chair. 
Table 20

Summary Stat1stics For Duration: Seven Targets

MN

Friend

Mother/father

Brother/sister

Teacher

stranger

Pet

Table/chair
44.22

8.65

15.25

10.05

19.69

16.34

.22
SD

49.94

10.51

18.73

12.43

43.51

33.86

The age $x$ sex $x$ target interaction was not significant. Two of the three "two-way" interactions were significant. The exception here was the sex $x$ target interaction. The age $x$ sex interaction was significant, as was the age $x$ target interaction.

\section{Aqe By Sex}

The age $x$ sex interaction was further examined with simple effects tests, and where appropriate, Newman-Keuls post hoc comparisons. The means and standard deviations for males and females across the three age levels appear in table 21 below. An analysis of sex differences at the varlous age levels revealed slgniflcant differences at the 6-7 year level: $F(1,24)=33.38, P<.05$, and the 11-12 year level: $F(1,24)=23.90, p<.05$. There were no significant male/female differences among the 8-9 year old children: $F(1,24)=0.00, P=>.05$. It is interesting to 
note that among the younger chlldren $(6-7)$, it is females who perceive significantly longer eplsodes of anger, but that among children 11-12, the results are reversed and males percelve longer perlods of anger.

There were age effects for both males: $F(2,24)=$ 76.57, $\mathrm{p}<.05$, and females: $F(2,24)=9.14, \mathrm{p}<.05$. The Newman-Keuls procedure Indicated the youngest group of girls, ages 6-7, perceived signiflcantly shorter episodes of anger than did the two older groups.

Table 21

Summary statistics For puration: Age $\underline{x}$ Sex

\begin{tabular}{lrcrc} 
& \multicolumn{2}{c}{ Males } & \multicolumn{2}{c}{ Females } \\
$6-7$ & 1.71 & 1.84 & 18.51 & 33.05 \\
$8-9$ & 9.94 & 30.80 & 9.85 & 15.92 \\
$11-12$ & 36.15 & 42.26 & 21.91 & 32.75 \\
\hline
\end{tabular}

The Newman-Keuls procedure on the three groups of boys demonstrated significant differences among all three groups, with the 8-9 year old boys reporting significantly longer perlods of anger than the 6-7 year olds, and the 1112 year old boys reporting significantly longer experiences than the 8-9 year old boys. 
Age By Target

A follow-up of the age $x$ target interaction was also conducted. Table 22 displays the means and standard deviations for each of the age groups across the seven targets. An analysis of perceived duration across various targets at the three age levels revealed significant effects at the 11-12 year old level: $F(1,24)=16.66, p<$ .01. There were no significant target effects at the 6-7 year level: $F(1,24)=1.69, p<.05$, or the $8-9$ year level: $F(1,24)=1.75, p>.05 . \quad$ The Newman-Keuls test performed on the seven targets for the 11-12 year old children revealed that most of the differences at this age level involved "friends." Children in this age range perceive an "episode" of anger involving a friend to be signiflcantly longer than a bout of anger directed at any of the other six targets. In addition, the perceived duration of anger involving inanimate objects, tables or chalrs, was significantly less than an "episode" of anger Involving elther a sibling or a pet. 
Table 22

Summary statistics For Duration: Age x Target

\begin{tabular}{lrrrrrr} 
& \multicolumn{2}{c}{$6-7$} & \multicolumn{2}{c}{$8-9$} & \multicolumn{2}{c}{$11-12$} \\
\hline Frlend & 17.09 & 26.64 & 24.07 & 8.55 & 91.50 & 53.31 \\
Mo/fa & 4.35 & 7.20 & 3.16 & 2.32 & 18.43 & 9.45 \\
Bros/s1s & 5.61 & 7.01 & 5.76 & 3.07 & 34.38 & 19.41 \\
Teacher & 6.38 & 9.95 & 6.32 & 3.16 & 35.01 & 52.69 \\
pet & 8.45 & 15.31 & 5.36 & 3.12 & 35.01 & 52.69 \\
tab/char & .13 & .17 & .33 & .19 & .20 & .30 \\
\hline
\end{tabular}

A series of simple effects tests were run to investigate age effects for each of the seven targets. significant differences were found for three of the seven targets. These were; frlends: $F(2,24)=27.01, p<.01$, Brother/sister: $F(2,24)=4.40, p<.05$, and pets: $F(2$, $24)=4.22, \mathrm{p}<.05$. There were no significant age differences involving the other four targets: mother/father: $F(2,24)=1.15, p>.05$, teachers: $F(2,24)$ $=0.66, \mathrm{p}>.05$, strangers: $F(2,24)=2.26, \mathrm{p}>.05$, or tables/chairs: $F(2,24)=0.00, p>.05$.

The Newman-Keuls procedure conducted on percelved duration of anger involving a friend revealed a significant difference between the oldest group of children (11-12) and the two younger groups $(6-7$ and 8-9). The 6-7 year old group did not differ significantly from the 8-9 year old group. However, The 11-12 year old children perceived an episode of anger directed at a friend to be significantiy longer, compared to either the 6-7 or 8-9 year old 
chlldren.

When the target of anger is a brother or sister, the results of the Newman-Keuls procedure suggest the 11-12 year old children perceive a significantly longer episode of anger, compared to both the 6-7 and $8-9$ year old children. These two younger groups were not significantly different in this regard.

A similar pattern of findings emerged when the target of anger was a pet. The 11-12 year old children report significantly longer periods of anger compared to both the 6-7 and 8-9 year old children. There is again no significant difference between the two younger groups.

\section{Perceptions of Sex Differences}

The issue of perceived sex differences or similarities in anger was explored by asking children the question "Do you think boys and gixls get mad the same?" It was hypothesized that older chlldren would be more likely to percelve sex differences in anger. The results presented In table 23 support this idea. There was a significant age difference. The follow-up analysis revealed the 11-12 year old children were slgniflcantly more likely to percelve sex differences in anger: $\quad X 2(2)=8.13, P<.05$. The difference between the two younger groups was nonsignificant: $\times 2(1)=$ 
1.50, P>.05. There were no signiflcant sex differences: $\mathrm{X} 2(1)=1.50, \mathrm{P}>.05$.

Table 23

Chi square analysis of perceptions of sex differences in anger

$$
\text { 6-7 } 8-9 \quad 11-12
$$

\begin{tabular}{|c|c|c|}
\hline different & 5 & 3 \\
\hline not different & 5 & 7 \\
\hline
\end{tabular}




\section{DISCUSSION}

The present study found support for many of the hypotheses advanced at the start of this investigation. Children's perceptions of anger varied considerably depending on age and sex of the chlld, and the particular target of anger. The following discussion begins with a review of the results for the five components of anger under study.

\section{Instigations}

The results of both the open-ended and structured Interviews indicated that older children percelve a larger set of instigations which may result in anger. When children were asked the question "when would it be alright to get angry?" The younger children portrayed an angry subject who is the target of aggression, while older children showed a tendency to include violations of interpersonal or social rules.

Aver111's (1982) survey of anger with adults offers an interesting comparison to these findings. over sixty-two percent of his subjects acknowledged that "violations of socially accepted ways of behaving or widely shared rules of conduct" were "somewhat" or "very much" involved in the Incident that made them angry. In contrast less than thirty-nine percent reported that "possible or actual property damage" or "physical injury and/or pain" were 
Involved.

These findings may also be interpreted in the context of Plaget's (1932) discussion of chlldren's moral Judgements. He documents a shift in middle childhood from a system of "moral realism" that narrowly focuses on consequences of acts to a "morality of reciprocity" in chlldren ages 9-11 that involves a different conception of social rules in which feelings, perceptions, and intentions of others are used in fudging their behavior.

The structured approach demonstrated the $11 \mathrm{kel}$ ihood of acknowledging anger to certain forms of instigations was also a function of age. The most striking example of this was the difference between 6-7 year old children and the two older groups with respect to attacks on self-esteem. There was a dramatic increase with age in the number of chlldren acknowledging the possiblity of anger to such instigations. From a cognitive perspective this could be interpreted in terms of a more elaborated "self schema" in older chlldren (cf Plaget, 1932) and/or an Increase in strivings for autonomy and independence occurring in middle ch1ldhood (Lee, 1976).

The hlghest level of instigations, the social or ethical transgressions, were expected to yleld the most dramatic age differences. The findings were inconclusive. There appeared to be little difference between the youngest and oldest children at this level. On closer inspection of the actual responses it became clear the youngest children 
were interpreting the questions in a manner systematically different from either of the two older groups. Children in the 6-7 age group interpreted questions at this level in a very personal way. When asked, for example, "do you think kids get angry when they see a man or lady getting money from someone else?" The youngest children took this as a "famlly issue" in which a sibling or frlend would get money that should have gone to them. The older children (8-9 and 11-12) apparently were able to evaluate these kinds of questions in a less personal manner and tended to see the possiblilty of anger at witnessing acts of stealing, littering, or intentionally harming another.

It should be noted here the more egocentric responses of the younger children are quite consistant with the original hypothesis concerning this class of instigations. It was expected that younger children would have difficulty conceptualizing an angry state as a result of a violation that did not directly involve them. What the findings perhaps show is that if young children are asked to consider anger in connection with a violation they will tend to personalize the violation even if the transgression is not presented as something happening to them. This could be due to the generally more egocentric style of younger children (Piaget, 1960) and their relatively undeveloped role-taking skills (Flavell, 1977; Selman, 1974). 


\section{Bodily Reactions}

The results suggest that older children are more capable of conceiving of bodily reactions that might accompany anger. The average 11-12 year old child was able to name twice as many bodily reactions as a 6-7 year old child. A possible interpretation for this age trend is provided by Fisher (1986), who after reviewing much of the work prior to 1985 on development of body perception concludes that age nine may well represent one of several points of "special acceleration" in the build-up of the body image. He cites a "real spurt" in knowledge concerning body parts and body functions, ability to draw human figures, and marked increase in accuracy of body $\mathrm{s} 1 \mathrm{ze}$ estimation.

Females in the present study perceived significantly more bodily reactions than males. Research with adults has revealed very few sex-differences with respect to anger (Allen \& Haccoun, 1978; Averill, 1982; Tavris, 1980.) However, investigations of sex-differences in children's ability to perceive their bodies suggest that female children more quickly and easily master various developmental body image problems in comparison to male children (Fisher, 1986.) Fisher (1972) has shown that from about the age of three girls tend to have more clearly articulated body boundaries than boys. Katcher and Leven (1955) demonstrate that female children develop a clear 
Image of their relatively smaller size (vs adults) earlier than males.

As expected there was no single bodily reaction that emerged as predominate in children's conceptions. Great varlability in terms of individual differences were noted for all age groups. This is consistent with the adult literature. Earlier studies such as those by Davitz (1959) and Gates (1962), and the more recent investigation by Averill (1982) have all found great individual differences. When bodily reponses were placed in categorles some interesting age trends emerged. The 8-9 year old children were more likely to report pain reaction involving speciflc body parts, e.g., headaches, stomache pains etc, while the 11-12 year old children were more apt to report nonspecific or global feelings of stiffness or tightness.

The research with adults has also uncovered a perception of general or nonlocalized tension. In Davitz's (1969) study, which relied on adults' self-reports, approximately sixty percent of the subjects endorsed tension in the "whole body." Ninety-three percent of the subjects in Averill's (1982) survey reported that "general tension" was "somewhat" or "very much" involved in their experiences.

It is not clear why "general tension" would emerge as the most frequently percelved bodily reaction of anger among adults and older children. From a more cognitivephenomenological perspective one could speculate that 
tension is produced because anger is a highly interpersonal emotion and involves a committment to act on a perceived violation (Averill, 1979; Solomon, 1976). The feeling that one must act may play a part in the generation of tension. Another possible interpretation is that tension occurs because poeple have to struggle with containing their "negative affect." Along these 1 ines Trabasso and schwartz (1984) have demonstrated that by the time children reach the age of 11 or 12 they have come to appreciate the fact that a person may feel one emotion while expressing another. It would be reasonable to assume that when a child is able to reflect on their own feelings in this manner they may be subject to other thoughts, feelings, and bodily reactions as a result. Finally, one could discuss the age trends from a social learning perspective (Bandura, 1986). Among 8-9 year old chlldren a "pain" analogy may be more sallent than a "tension" model. The younger chlld has a great deal more experience with pain. Parents have been teaching them about pain since they were infants by interpreting and labeling their experiences and through modelilng of thelr own "paln behavior" (cf. Wittgenstein, 1971). 


\section{Consequences}

The results show that approximately forty percent of the outcomes percelved by chlldren in this age range could be classified as "constructive" while roughly sixty percent could be labeled. "destructive." Averill's (1982) survey of adults demonstrates the difficulty of interpreting "overall" findings of this sort. Although most subjects in Averill's study reported dysphoric affective reactions following anger such as "1rritability", "hostility", and "depression", when asked to evaluate the benefit or harm of the experience over sixty percent reported the experience was generally beneficial rather than harmful for both the angry subject and the target.

Among older children, males were more likely to perceive distructive outcomes as a result of anger. As noted earlier, few sex differences tend to emerge in research on adult anger (Allen \& Hacuun, 1979; Averill, 1982; Tavr1s, 1983). In at least one study (Aver111. 1982), however, women did report less overt aggressive consequences when angry.

The findings offer partial support for the general hypothesis that older children are more aware of constructive aspects of anger. The open-ended inguiry revealed dramatic age differences when children were asked "what are some good ways to show you are angry?" Among the 6-7 year old chlldren, only 3 of 10 could provide a 
response to this question. In contrast, all of the children in the 11-12 year old group could think of at least one "good way" to show anger.

Children perceive different outcomes from anger directed at different targets. This was a consistent finding across all age levels, but the differences were most striking in the 8-9 year old group. Children in this age range were more likely to expect destructive consequences when the target was a teacher who had the authority to "punish" them or a strager who might harm them. They also belleved that anger directed at an inanimate object such as a table or chair was more $11 \mathrm{kely}$ to result in a destructive outcome. In this case they expected the target to be the recipient of their destructive actions.

Among the 6-7 and 11-12 year old children, the target effects were still apparent but less striking. Two factors may be responsible for this finding. There was a great decline with age in the number of children who expected anger directed at a stranger to result in destructive consequences, but there was (otherwise) a general increase with age in the percentage of destructive outcomes for most of the other targets.

At one level the results of this section seem to- offer contradictory findings. The open-ended inquiry suggested older children were more aware of constructive aspects of anger while the structured approach seemed to show an 
age-related increase in the number of destructlve outcomes percelved. A more detalled analysis of children's responses to each of the seven targets sheds some light on this apparent inconsistancy. When children's responses to targets which could be labelled "superiors", 1.e., their parents, teachers, and strangers, were combined and examined a dramatic age trend was evident. There was a steady increase in the percentage of "constructive" outcomes percelved. Among 6-7 year old chlldren, only 188 of the percelved outcomes involving superiors could be classifled as "constructive". For children ages 8-9 and 11-12 the percentage of percelved "constructive" outcomes rose to 408 and 448 respectively.

The increase in perceived destructive outcomes among older chlldren essentially involved targets of equal (sibling or friend) or lesser (pets or tables and chairs) status. What this perhaps suggests is that older chlldren are more aware of the constructive aspects of anger because 1) they are more aware of "good ways" of expressing the ir anger, and 2) they may have learned of the need to handle their anger in a more controlled fashion when the target is a superior.

\section{Aggression}

Approximately thirty percent of the outcomes perceived by chlldren in this age range (6-12) could be classifled as "aggressive" while seventy percent were labeled 
"nonaggressive." This is consistant with the recent literature on anger and aggression which tends to downplay the role of anger in aggression (Baron, 1977). Females were much less likely to percelve aggressive outcomes as a result of anger. This was a consistant finding across all the age groups but the differences increased with age. The male/female discrepancy was minor among 6-7 year old children, but within the 11-12 age group males were far more likely to perceive aggressive outcomes. One could interpret the widening gap between the sexes purely in terms of soclalization (cf. Bandura \&alters, 1960). However, an explanation based on maturational factors, and rooted in a more blological account of sex-differences in agression would also be consistent with these findings (Maccoby \&acklin, 1974).

Children's tendencles to percelve aggressive vs. nonaggressive outcomes were also a function of the particular target. This was again most clearly seen in the 8-9 age group. Chlldren in this age range expected that anger involving a stranger would be less likely to precipitate an aggressive outcome than anger directed at a sibling or inanimate object. Children in this age range also belleved that if the target was an inanimate object, they would be more likely to expect an agressive outcome than if the target were a parent, teacher, friend or pet. The target differences among $6-7$ and $11-12$ year old children, although present, were less striking. A closer 
inspection of children's responses to the varlous targets reveals why this may have occurred. First, the distinction between strangers (less aggression) and inanimate objects (more agression) made by the $8-9$ year old children was not made by the younger or older children. The 6-7 year old children were not as likely as the 8-9 year old children to percelve an agressive outcome when the target was an inanimate object, while the 11-12 year group was more likely than the 8-9 year old group to perceive an agressive outcome when the target was a stranger. secondly, the distinction between inanimate objects (more aggression) and parents, teachers, and friends or pets (less aggression) was also not made by the youngest or oldest group. The 6-7 year old chlldren were not as likely to perceive an aggressive outcome when the target was an inanimate object, while the the 11-12 year old children were more likely to percelve an aggressive outcome when the target was a teacher, friend, or pet. It should be recalled, however, that no overall age differences emerged with respect to number of children who percelved aggressive outcomes.

\section{Duration}

The duration of anger perceived by the 11-12 year old chlldren was much longer than the average "episode" perceived by the two younger groups. While both the 6-7 and 8-9 year old groups reported experiences that averaged 
approximately ten hours, the older children perceived much longer bouts of anger, averaging nearly thirty hours. In Averill's (1982) survey which relied on adult self-reports, the mean duaration for anger was "1-2 hours" but the mode was "more than a day".

The 1ssue of age differences in duration of anger can become quite complex. One needs to distinguish possible age differences in duration of actual experiences of anger from changes in children's abllity to recall past experiences of anger. Both processes may be implicated in the present study. It is 11 kely that children will remain angry longer as they become older and attentional and other memory related capacities develop (Hagen, 1967). The 1ssue of recall is interesting because it highlights the constructive and reconstructive nature of memory (Flaveli \& Wellman, 1977) and the role of developing categorization and labeling (e.g. of emotions) in improving children's recall of events and experiences.

There were no overall sex differences in duration, but on closer inspection a sex related trend was noticable. The 6-7 year old females reported much longer perfods of anger than their male counterparts. Among 8-9 year old chlldren no signiflcant differences were observed. But among the 11-12 year olds it was the male chlldren who percelved much longer eplsodes of anger. While there is no ready explanation for this pattern of findings, one could hypothesize a shift in the functional value of anger 
between the ages of 6 and 11. That is, the functions of anger may change with the age of the child and these may carry different implications for the two sexes.

older chlldren percelved differences in the duration of anger involving different targets. Children ages 6-7 and 8-9 did not report significant differences in the duration of anger directed at the varlous targets. It was only the 11-12 year old group that made this discrimination (see Flgure 1). Not surprisingly the results showed that children in this age range expected an experience of anger involving a frlend to last much longer than an eplsode of anger directed at any of the $s i x$ other targets.

A number of factors could be brought in to explain why chlldren would expect their experiences of anger towards frlends to last a relatively long time. Some of these factors might have little to do with duration per se. It may be, for example, that most chlldren have more oppurtunities to experlence anger with friends. Hence they may be confusing frequency with duration. But another Interpetation is possible if one considers fridhandler and Averill's (1982) conclustons about percelved duration of anger. They report that surveys with adults suggest people use duration to "reconstruct intensity" of an emotional experience, 1.e., it is not that intensity determines duration. Rather duration is constitutive of intensity, 1t helps to define an experlence of anger as more or less intense. Along these lines, Fridhandler and Averill 
(1982) found that of all the instigations listed by their subjects, the one which correlated significantly with duration involved an interpersonal violation by a close other. From this perspective one could hypthesize that children expect experiences of anger directed at friends to last longer because they have some awareness of the intensity of anger they experience when friends are Involved.

\section{Perceptions of Sex Differences}

Male and female children did not differ in their perceptions of whether or not "boys and girls got mad the same." But there was a dramatic age difference. The older children were significantly more likely to perceive sex-differences in anger. While only 3 of 10 children, ages 8-9, belleved there were differences in the way boys and girls got mad, 9 of 10 chlldren in the 11-12 year old group percelved differences in this regard. When children's responses were examined more closely an interesting shift in attributions was noted. The younger chlldren were able to percelve commonalities among males and females arsing as a result of similar instigations. They typically felt that boys and girls would get mad the same because they would "see the same thing" and consequently both would become angry. The older chlldren (11-12) percelved differences in the way boys and girls got 
angry which were rooted in personal characterlstics of the angry subject, particularly expressive and motoric components, e.g., "boys yell and girls scratch".

Implications

Implications of the above findings will follow shortiy. But first, some of the possible limitations of the present analysis should be discussed. The two aspects of this investigation which might invite criticism are one, the relevance of chlldren's conceptions, and two, the relevance of self-report data in general. As was noted earlier the focus of the present study is on children's conceptions of anger, and not neccessarily their experience. But granted, one assumption guiding this investigation is that information pertaining to children's perceptions of anger may shed some light on how children experlence anger. Along these lines, the overall pattern of results does provide some evidence in this regard. Many of the findings were consistant with previous lab based and observational research of children's anger and related processes.

There are often good reasons to be skeptical of selfreport data. And it is true that factors such as social desirability, repression, selective attention, etc., play an important role the area of emotion. Nevertheless it has been correctly polnted out that self-report data is not 
inherently doomed (cf. Berkowitz, 1985). To begin, the notion that social desirability is a shortcoming is true, if one accepts the presupposition that it is a confound. A role theorist would entertain some different hypotheses (cf. Hogan, 1980). The issue of "validity" cannot be discussed in a vacuum. This point is occasionally addressed as researchers publish articles in defense of their own data, but many invoke such notions as "external validity", "Internal validity", or "confounds" as blanket criticisms. The validity of a set of findings is closely tied to the kind of inferences one hopes to make. When the emphasis of an investigation is not on internal cognitive processes but rather soclal norms and expectations that help to define a phenomenon, the inferences are made to these norms and any methodological objections need to take this into account. Finally, many of the criticisms made of self reports have been applied to most other forms of data, including overt behavior and physiological responses (Aver111, 1983).

Implications for Theories of Emotion

In terms of theoretical implications, the results of this study could be viewed in a number of ways. It is neither possible nor desirable to discuss the relevance of the findings for the countless "theorles" of emotion. It seems more appropriate to present a briefer discussion focusing on emotion development, and more specifically the 
lssue of continulty vs discontinuity in emotion development.

Many theorists who emphasize continuities in emotion development tend to draw upon physlological and/or evolutionary models of explanation and posit some "core" or "basic" affects that emerge preformed (Bridgeman, 1929: Izard, 1970; Plutchlk, 1960; Young, 1971). From this perspective many of the age trends might be explained as a "canalization" phenomenon, and the target differences attributed to more "selective" discharge of the angry affect among older children. The individual differences in perceptions of bodily reactions might be harder to explain unless one assumes these bear little relationship to "actual" bodlly responses.

A problem which often arises with "core" views of emotion can be 11 lustrated with Bowers' (1981) Associative Network Theory of Memory and Emotion. According to this view each distinct emotion has a specific "node" or unit in memory that collects together many other aspects of the emotion that are connected to it by "associative pointers". When these emotion nodes are activated by physiological or symbolic verbal means the emotion unit transmits excitation to those nodes that produce the pattern of autonomic arousal, expressive behavior, etc., commonly asslgned to that emotion. The problem arises when one considers the full implications of successively removing the units assoclated with the emotion nodes. If autonomic 
arousal patterns are stripped away, expressive and motoric components eliminated, and cognitive appraisals removed, what's left? What is the nature of the "node" or remaining "core". One might object at this point that many theorists would tend to equate one of the associated components with the emotion and Bowers' problem would in fact become a pseudo issue. But the fact that emotional reactions do not occur as consistant packages of facial expressions, particular bodily reaction, etc. is the reason Bower and others had to relegate many of these processes to "assoclated components" (Kagan, 1978).

A constructivist approach offers an alternative view (Aver111, 1980; Gergen, 1979; Kagan, 1978). From this perspective emotions are responses of the whole person. There is no single neccessary or sufficient element that comprises an emotion. Rather they are "constructed" from blological, social, and psychological elements. These elements, including such things as cognitive appraisals are not "associated" with the emotion, they help to constitute the emotion. Within a social constructivist framework the "principles of organization" are social norms and rules.

Those who favor a constructivist approach argue for considerable discontinuites in emotion development (Kagan, 1978). From this perspective the various age, sex, and target differences found in the present study reflect fundamental changes in anger over the course of 
development. The increased set of instigation to anger among older children could be interpreted along the lines proposed by theorists such as Kagan (1978) and stipek (1983) who hold that development of cognitive-evaluative capacities help to determine the emotion a child can experience. some emotions may rest on very basic evaluations and even very young children may be able to "evaluate" that something is "wrong", but the evaluation (and perhaps the emotion) is altered when the child develops a capacity to assign responsiblilty for the "wrong" or the ability to juage another's intent.

From a constructivist perspective the target effects found in the present study should not be interpreted simply as more selective discharge by the older children. The increased target discrimination among older children could well be understood as an aspect of the "appropriateness" of anger reflecting greater awareness of underlying social norms. As was noted earlier most instances of anger involve human targets, and typically the person is a close frlend or acquaintance of equal status. Thus it should not be surprising that older children percelved more constructive outcomes when anger involved superiors, or expected the duration of anger to be relatively long when it involved a friend but extremely brief when an inanimate object was the target.

of course the notion that anger may be "appropr late" or "Inappropriate" is not a new idea Invented by the recent 
"assertiveness tralning" experts. The following passage is from Aristotle's Ethics.

Anyone can get angry-that is easy;........but to do this to the right person, to the right extent, at the right time, with the right motive, and in right way, that is not for eveyone nor is it easy; wherefore goodness is both rare and laudable and noble (N1chomachean Ethics, 1109a25)

Among both chlldren and adults the research shows great individual differences in self-reports of bodily reactions during anger (Aver111, 1982, Davitz, 1969). The constructivist response is that this tells us more about Individual differences than any particular physiological patterning for anger. Some would even argue the specific blological responses are themselves social constructions. Hence we have such phrases as "love comes from the heart" and so on. The psychosomatic literature, particularly that dealing with chlldhood pain, often presents compeliling accounts of "pain laden" or "psychosomatic" families whose members serve as models for one another (Appley, 1980; Minuchin, 1959).

What is soclalized?

within the past decade it has become increasingly popular to discuss social demensions of emotion. In a 1983 1ssue of the American Psychologist, Averill commented on the apparent demise of cognitive formulations 
in this area, and profected a "new wave" of social theories. Lewis and Saarni (1985) recently edited an entire volume on "the socialization of emotions".

While it is beyond the scope of the present discussion to consider the many forms which a "social approach" to emotion might take, a few words about what exactly is being "socialized" may be in order.

There are some fundamental differences between the social constructionist position outlined above and the view of emotion shared by many of the current investigators studying their "socialization". The most serious of these involves one's basic notion of what is an emotion. The view shared by many of those currently exploring the socialization of emotion is that some underlying core or thing exists, which is the emotion. The role of socialization is to modify or shape this core into a socially appropriate form. In contrast a constructionist position rests on the notion that emotions are not "things out theren, but rather social products or artifacts (Averill, 1882; Gergen, 1985).

The opinion of this writer is that a social constructionist stance represents a more interesting and promising departure from traditional views of emotion. The notion of a "socialized core" runs into the same problems that plagued the more traditional core view; Namely, how does 
one account for the lack of neccessary and suffcient (core) elements across different emotions and even within the same emotion over time? It may be fair to say at this point in time that much of the work on emotion and socialization is theoretically sterile, in that it does not go very far beyond the classic blological core view, and seems for the most part to merely suggest that socialization can strongly affect this core.

\section{Future Research}

The present analysis dealt with childrens' conceptions of anger. As was mentioned earlier, many of the findings were consistent with lab-based and observational data. It will be important in future work to obtain additional observational data on the various parameters of anger examined in this investigation.

A replication study with a larger sample of children is needed before any of the findings can serve as "normative data". Much of the study revolved around questions that asked chlidren to consider other "kids $11 \mathrm{ke}$ them". It would be interesting to compare the present findings to results obtained by asking the child directly about their own experiences of anger. Finally, the present study did not focus on differences pertaining to children as targets vs subjects of anger. More work is needed in this area since a number of studies have shown that much of the aggression that follows from 
adult anger is in fact directed towards children (Averill, 1982; Richardson, 1929). 
BI BL I OGR APHY

Allen, J.G., \& Haccoun. (1976) Sex differences in Emotionality: A multidemensional approach. Human Relations, 29, No. 3, 345-363.

Apley, J. (1976) Pain in childhood. Journal of Psychosomatic Research, 20, 383-389.

Aristotle. (1966) Rhetoric. (W.R. Roberts, trans.) In The Works of Aristotle, 11, W.D. Ross, ed. (1st ed., n.d., reprinted, 1966), Oxford University Press.

Aver111, J.R. (1983) studies on anger and aggression: Implications for theories of emotion. American Psychologist, 38, No. 11, 1145-1160.

Averi1l, J.R. (1982) Anger and Aggression: An essay on emotion. New York: Springer-Verlag, 1982.

Aver111, J.R. (1979) Anger. In H. Howe \& $R$. Dienstbier (Eds.), Nebraska Symposium on Motivation, 26, Lincoln: University of Nebraska Press.

Bandura, A. (1986) Soclal Eoundations of thought and action: A social cognitive theory. Englewood, NJ: Prentice-Hall. 
Bandura, A., Ross, D., \& Ross, S.A. (1963) Imitation of film-mediated aggressive models. Journal of Abnormal and social Psychology, 66, 3-11.

Baron, R.A. (1977) Human aggression. New York: Plenum.

Bowers, G. H. (1981) Mood and memory. American Psycholog1st, 36, No. 2, 129-148.

Bridges, K.M.B. (1932) Emotion development in early Infancy. Ch1ld Development, 3, 324-341.

Berkowitz, L., \&onnerstein, E. (1982) External Validity is more than skin deep: Some answers to criticism of laboratory experiments. Amerlcan Psychologlst, 37, No. $3,245-257$.

Davidson, R. (1984) The role of the cerebral hemispheres in emotion and mood. In C.E. Izard, J. Kagan, \& R.B. Zajonc. Emotions, cognitions, and behavior. New York: Cambridge University Press.

Davitz, J.R. (1969) The language of emotion. New York: Academic Press. 
Elkind, D. (1964) Plaget's semi-cilnical interview and the study of spontaneous religon. Journal for the Sclentific study of Religon, 12, No. 4, 234-239.

Eron, L.D., Walder, L., Huessmann, L.R., \& Lefkowitz, M.M. (1974) The convergence of laboratory and fleld studies on the development of aggressive behavior. The Hague: Mouton.

Fisher, S. (1986) Development and structure of the body Image., Vol. 1. New Jersey: Erlbaum.

Fisher, S. (1972) Influencing selective perception and fantasy by stimulating body landmarks. Journal of Abnormal Psychology, 79, 97-105.

Flavell, J.H. (1977) Cognitive Development. Englewood Cliffs, N.J.: Prentice-Hall.

Freud, S. (1962) Three contributions to the theory of sex. Translated by A.A. Br111. New York: E.P. Dutton.

Fridhandlex, B.M., A Averill, J.R. (1982) Temporal demenstons of anger: An exploration of time and emotion. In J.R. Averill (Ed.) Anger and aggression: An essay on emotion. New York: springer-Verlag. 
Gates, G.s. (1926) An observational study of anger. Journal of Experimental Psychology, 9, 325-331.

Gergen, K. (1985) social construction in psychology. New York: Springer-Verlag.

Goodenough, F.L. (1931) Anger in young ch1ldren. MInneapolis: Unlversity of Minnesota press.

Hagen, J.w. (1967) The effect of distraction on selective attention. Ch1ld Development, 38, 685-694.

Hall, G.S. (1883) The contents of children's minds. In W. Dennis (1972) (Ed.) Historlcal Readings in Developmental Psychology. New York: Appelton-CenturyCrofts.

Harris, P.L., Olthof, T., \& Terwogt, M.N. (1981) Children's knowledge of emotion. Journal of child Psychlatry and Psychology, 22, 247-261.

Harwick, C.s., (1971) Language learning in Wittgenstein's later phllosophy. The Hague: Morton and Co.

Izard, C.E. \& Buechler, S. (1979) Emotion 
expressions and personality integration in infancy. In C.E. Izard (Ed.), Emotions in personality and psychopathology. New York: Plenum Press.

Kagan, J., (1978) on emotion and its development: A working paper. In M. Lewis and L.M. Rosenblum (Eds.) The devlopment of affect. New York: Plenum Press.

Katcher, A., \& Levin, M. (1955) Children's conceptions of body size. Child Development, 26, 103-110.

Levine, L.s. (1962) Personal and social development: The psychology of effective behavior. New York: Holt, Rinehart, and winston.

Lewis, M., \& Saarn1, C. (1984) (Eds.) The socialization of emotion. New York: Plenum,

Lyons,. (1980) Emotion. Cambridge: Cambridge University press.

Maccoby, E.E., \& Jacklin, C.N. (1974) The psychology of sex differences. Stanford, Callfornia: stanford University Press.

Mandler, G. (1979) Emotion. In E. Hearst (Ed.), 
The first century of experimental psychology. Hillsdale, NJ : Erlbaum.

Masters, J., \& Carlson, R. (1984) Children's and adult's understanding of the causes and consequences of emotional states. In C.E. Izard, J. Kagan, \& R.B. Zajonc (eds.), Emotion, cognition, and behavior. New York: Cambridge University Press.

Minuchin, S., Rosman, B.L., \& Baker, L. (1978) Psychosomatic familles: Anorexla nervosa in context. Cambridge: Harvard University Press.

Plaget, J. (1981) Intelligence and affectivity. In T.A. Brown \& C.E. Kaegi (Eds.). Palo Alto, California: Annual Reviews Inc.

Plaget, J. (1960) The lanquage and thought of the child. London: Routledge. (originally published, 1923)

Plaget, J. (1932) The moral fudgement of the child. New York: Harcourt Brace.

Plutchik, R. (1980) Emotion: A psychoevolutionary synthesis. New York: Harper and Row.

Richardson, F. (1918) The Psychology and Pedaqogy 
of anger. Baltimore: Warwick and York.

Rorty, A.E. (1980) Explaining emotions. Berkeley: University of California press.

Ross, L. (1977) The intuitive psychologist and his shortcomings: Distortions in the attribution process. In L. Berkowitz (Ed.), Advances in experimental social psychology. Vol. 10. New York: Academic Press.

Selman, R.L. (1971) Taking another's perspective: Role taking development in early childhood. Child Development, 42, 1721-1734.

Sherman, M. (1927) The differentiation of emotional responses in infants. Journal of Comparative Psychology, I, 265-284.

slaby, R.G. (1974) The effects of aggressive and altruistic verbalizations on aggressive and altruistic behaviors. In J. de witt \& W.W. Hartup (Eds.), origins and determinants of agqression. The Hague: Mouton.

solomon, R.C. (1976) The passions. Garden City, N.Y.: Doubleday (Anchor Press). 
stipek, D.J. (1983) A developmental analysis of pride and shame. Human Development, 2 , No. 2 .

Tavris, C. (1982) Anger: The misunderstood emotion. New York: simon and schuster.

Trabasso, T., \& Schwartz, R.M. (1984) Children's understanding of emotions. In C.E. Izard, J. Kagan, \& R.B. Zajonc, Emotion, cognition, and behavior. New York: Cambridge University Press.

Watson, J.D. (1919) Psychology from the standpoint of a behaviorist. Philadelphia: Lippincott. (3rd Ed., $1929)$

Weiner, B., \& Graham, S. (1984) An attributional approach to emotion development. In C.E. Izard, J. Kagan, \& R.B. Zajonc, Emotion, cognition, and behavior. New York: Cambridge University Press.

Young, P.T. (1943) Emotion in man and animal. New York: Wiley.

Zajonc, R.B... Markus, S. (1984) The role of the motor system in emotion and cognition. In C.E. Izard, J. Kagan, \& R.B. Zajonc (eds.), Emotion, Cognition, and Behavior. New York: Cambridge University Press. 
APPENDIX A

structured Interview

INSTIGATIONS

1. SOME ADULTS GET ANGRY AT BEDTIME.

DO YOU THINK KIDS EVER GET ANGRY AT BEDTIME?

WHY OR WHY NOT?

2. ADULTS CAN GET ANGRY WHEN THEY EAT SOME KINDS OF FOODS. DO YOU THINK KIDS EVER GET ANGRY WHEN EAT SOME KINDS OF FOODS?

WHY OR WHY NOT?

3. SOME ADULTS NEVER GET ANGRY WHEN THEY GET DRESSED. DO YOU THINK KIDS EVER GET ANGRY WHEN THEY GET DRESSED?

WHY OR WHY NOT?

4. THERE ARE SOME ADULTS WHO GET ANGRY WHEN PEOPLE DO THINGS FOR THEM.

DO YOU THINK KIDS EVER GET ANGRY WHEN PEOPLE DO THINGS FOR THEM? 
WHY OR WHY NOT?

5. SOME ADULTS NEVER GET ANGRY WHEN PEOPLE SAY THINGS ABOUT THEM.

DO YOU THINK KIDS EVER GET ANGRY WHEN PEOPLE SAY THINGS ABOUT THEM?

WHY OR WHY NOT?

6. SOME ADULTS GET ANGRY WHEN PEOPLE DON'T ASK THEM POR HELP .

DO YOU THINK KIDS WOULD EVER GET ANGRY WHEN PEOPLE DON'T ASK THEM FOR HELP?

WHY OR WHY NOT?

7. SOME ADULTS NEVER GET ANGRY WHEN THEY SEE A STRANGER GETTING MONEY FROM SOMEONE ELSE.

DO YOU THINK KIDS CAN GET ANGRY WHEN THEY SEE A BOY OR A GIRL GET MONEY FROM SOMEONE ELSE?

WHY OR WHY NOT?

8. ADULTS SOMETIMES GET ANGRY WHEN THEY SEE TWO PEOPLE FI GHTING.

DO YOU THINK KIDS EVER GET ANGRY WHEN THEY SEE TWO PEOPLE FIGHTING? 
WHY OR WHY NOT?

9. SOME ADULTS NEVER GET ANGRY WHEN THEY SEE PEOPLE PUTTING THINGS INTO A RIVER. DO YOU THINK KIDS COULD GET ANGRY WHEN THEY SEE TWO PEOPLE PUTTING THINGS IN A RIVER?

WHY OR WHY NOT?

10. CAN YOU THINK OF WHEN IT WOULD BE ALRIGHT TO GET ANGRY ?

CONSEQUENCES AND DURATION

1. GROINUPS CAN GET ANGRY AT THEIR EREINDS SOMETIMES. DO YOU THINK KIDS GET ANGRY AT THEIR FRIENDS SOMETIMES? WHY OR WHY NOT?

2. ADULTS CAN GET ANGRY THEIR MOTHER AND FATHER. DO YOU THINK KIDS GET ANGRY AT THEIR MOTHER AND FATHER? WHY OR WHY NOT?

3. SOMETIMES ADULTS GET ANGRY AT THEIR BROTHERS AND 
SISTERS

DO YOU THINK KIDS GET ANGRY AT THEIR BROTHERS AND SI STERS?

WHY OR WHY NOT?

4. ADULTS CAN GET ANGRY AT TEACHERS SOMETIMES. DO YOU THINK KIDS GET ANGRY AT TEACHERS SOMETIMES?

WHY OR WHY NOT?

5. SOME GROTNUPS NEVER GET ANGRY AT STRANGERS DO YOU THINK KIDS GET ANGRY AT STRANGERS?

WHY OR WHY NOT?

6. DO YOU THINK KIDS EVER GET ANGRY AT PETS, LIKE CATS AND DoGs?

WHY OR WHY NOT?

7. DO YOU THINK KIDS GET ANGRY AT TABLES OR CHAIRS? WHY OR WHY NOT? 
CONSEQUENCES: PART TWO

1. DO YOU THINK ITS GOOD OR BAD TO GET ANGRY?

2. WHAT ARE SOME BAD WAYS TO SHOW YOU ARE ANGRY?

3. WHAT ARE SOME GOOD WAYS TO SHOW YOU ARE ANGRY?

BODILY REACTIONS

1. SOMETIMES GROWNUPS FEEL THINGS INSIDE THEIR BODY WHEN THEY GET ANGRY.

WHAT DO YOU THINK KIDS FEEL INSIDE THIER BODY WHEN THEY GET ANGRY?

HOW DO YOU KNOW THAT?

2. DO YOU THINK KIDS PEEL OTHER THINGS INSIDE THEIR BODY WHEN THEY GET ANGRY?

HOW DO YOU KNOW THAT? 